\title{
Revision of the Australian species of Hydropeza Sinclair (Diptera: Empididae: Ragadinae subfam. nov.)
}

\author{
BRADLEY J. SINCLAIR \\ Canadian National Collection of Insects and Canadian Food Inspection Agency, \\ K.W. Neatby Bldg., C.E.F., 960 Carling Ave., Ottawa, ON, Canada K1A 0C6, Canada \\ bradley.sinclair@inspection.gc.ca
}

\begin{abstract}
Nine new species of Hydropeza Sinclair from Australia are described (H. angulata sp. nov. (N. Queensland), H. aptera sp. nov. (Tasmania), H. cornuta sp. nov. (Queensland), H. curvata sp. nov. (N. Queensland), $H$. divaricata sp. nov. (N. Queensland), $H$. intricata sp. nov. (N. Queensland), $H$. queenslandensis sp. nov. (N. Queensland), H. tasmanica sp. nov. (Tasmania), H. unguicula sp. nov. (Tasmania)). In Australia, Hydropeza is currently widely disjunct in distribution, known only from Tasmania and northern Queensland (Wet Tropics), absent from intervening regions despite extensive surveys of rocky streams and creeks. The male terminalia are illustrated, distributions mapped and a key to species is presented. The subfamily Ragadinae subfam. nov. is proposed for the Ragas-group of genera (Dipsomyia Bezzi, Hormopeza Zetterstedt, Hydropeza, Ragas Walker, Zanclotus Wilder). A revised phylogeny of the species of Hydropeza, including species from New Zealand and Chile, is presented and discussed.
\end{abstract}

KEYWORDS. Diptera; Empididae; Hydropeza; new species; taxonomy; Australia

Sinclair, Bradley J. 2016. Revision of the Australian species of Hydropeza Sinclair (Diptera: Empididae: Ragadinae). Records of the Australian Museum 68(1): 1-22.

The genus Hydropeza Sinclair was erected for a New Zealand species described by Miller (1923), which was originally assigned to the Northern Hemisphere genus Trichopeza Rondani (Sinclair, 1999). There are ten New Zealand species and a single species described from Chile (Sinclair \& McLellan, 2004; Sinclair \& Plant, 2008).

In Australia, Hydropeza was initially recognized from a large-sized undescribed Tasmanian species collected from streams and rivers (Fig. 5). More recently this genus was discovered from northern Queensland, where a series of new species are represented. The apparent rarity of the genus is in part likely due to the curious habit of the adults which fly rapidly about small cascades and pools with all six legs skimming on the water surface, making them hard to see especially in shaded streams and very difficult to capture with sweep nets. The author used small dip nets to collect individuals, which were virtually invisible at the base of small cascades. In addition, the use of lights set next to streams, Malaise traps set across streams, as well as pitfall traps and yellow pan traps have proven effective in capturing specimens. This paper reports on the Australian biotic diversity of Hydropeza for the first time.

Hydropeza is assigned to the Ragas genus-group (Sinclair \& Cumming, 2006), which is herein elevated to subfamily rank. The new subfamily is newly diagnosed and discussed. 


\section{Material and methods}

This study was based on the examination of 229 adult specimens borrowed from or deposited in the following institutions or collections: Australian Museum, Sydney (AMS); Australian National Insect Collection, Canberra, Australia (ANIC); Canadian National Collection of Insects, Ottawa, Canada (CNC); Museum Victoria, Melbourne (NMV).

Terms used for adult structures primarily follow those of Cumming \& Wood (2009), except for the antenna and wing venation, where the terms of Stuckenberg (1999) and Saigusa (2006) are used, respectively. To facilitate observation, terminalia were macerated in hot $85 \%$ lactic acid and immersed in glycerin. All specimens are dried and mounted on pins. Label data of holotypes are cited in full, with original spelling, punctuation and date; lines are delimited by a slash mark (/), and a semicolon separates data quoted from different labels. Secondary type data are abridged and listed alphabetically.

The following abbreviations are used in the descriptions and material examined sections: $a c r$ - acrostichal setulae; bm-m — basal medial-medial crossvein; $c k$-creek; $\mathrm{CuA}$ anterior branch of cubital vein; $C u P$ - posterior branch of cubital vein; $d c$ - dorsocentral setae; $d m$ —discal medial cell; $M T$-Malaise trap; $N P$-National Park; $n p l$-notopleural setae; pal — postalar setae; $p h$ - posthumeral seta; $p p r n-$ postpronotal setae; presut spal — presutural supra-alar setae; psut spal-postsutural supra-alar setae; $R$-radial vein; sctl — scutellar bristles; $T$ - tergite; ypans - yellow pan traps.

A cladistic analysis of the species level relationships of the genus Hydropeza was performed using the parsimony program PAUP*4.0b10 (Swofford, 1998). A heuristic search with stepwise addition was implemented to find the most parsimonious trees using random addition sequence of taxa, tree-bisection-reconnection (TBR) branch swapping and 1000 random replications. All characters were unordered and of equal weight, MulTrees option in effect, with ACCTRAN optimization. The data matrix (Table 1) consisted of 22 morphological characters, including 2 multi-state characters (Table 2), compiled for 16 species of Hydropeza, which included all Australian and Chilean species and a selection of New Zealand species. Hormopeza senator Melander was used as the outgroup taxon and to root the trees.

\section{Taxonomy}

\section{Subfamily Ragadinae subfam. nov.}

Type-genus: Ragas Walker, 1837: 229.

Diagnosis. Males dichoptic or holoptic; eyes with or without ommatrichia; scape with setae (absent in Hormopeza Zetterstedt); labrum stout and recurved at least in females, lacinia freely projecting; apical epipharyngeal comb present (absent in Hydropeza); laterotergite bare (except Dipsomyia Bezzi); fore coxa with erect, spine-like setae (absent in Hormopeza); costa circumambient (although sometimes weakened posteriorly); $\mathrm{R}_{4+5}$ branched; apex of phallus often emitting membranous tube; female cercus short, broad with fine setae (Sinclair, 1999; Sinclair \& Cumming, 2006).
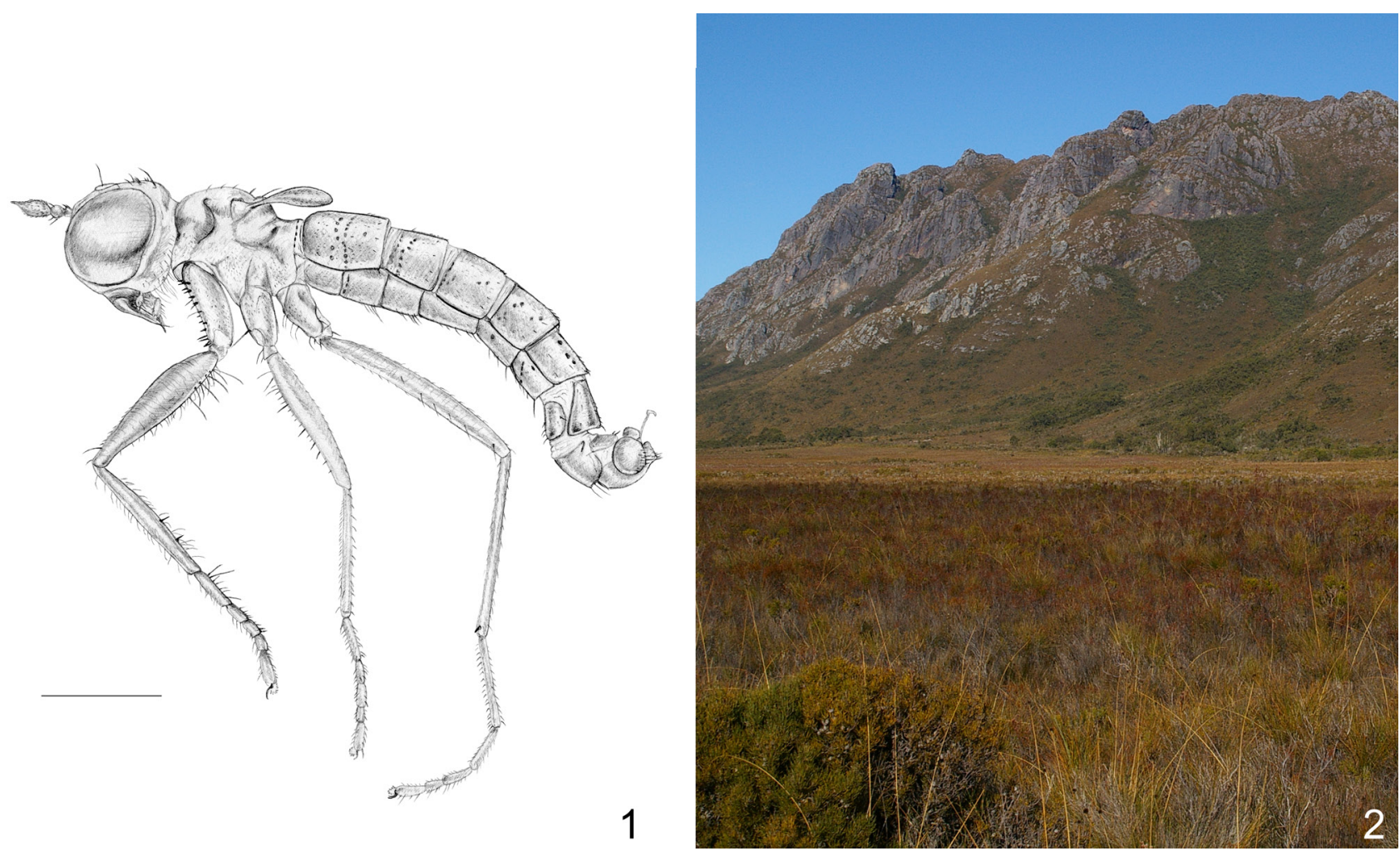

Figures 1-2. (1) Hydropeza aptera (drawn by Hannah Finlay). (2) McPartlan Pass, Tasmania, type-locality of H. aptera (photograph: M. Driessen). Scale bar $=0.5 \mathrm{~mm}$. 
Remarks. The Ragas genus group was first proposed by Sinclair (1999) and keyed out from other major groups of Empidoidea by Sinclair \& Cumming (2006). The group is herein given subfamily status, although its precise position within the Empididae remains unresolved (Sinclair \& Cumming, 2006). The subfamily is named to provide stability in Empidoidea nomenclature, and to highlight the importance of including this clade in future molecular and morphological phylogenetic studies.

The presence of Baltic amber species of Ragas Walker indicates that the subfamily is as old as the Dolichopodidae s.str. (minimum age: 40 million years) and could perhaps be found in Upper Cretaceous amber (Ulrich, 2003; Sinclair \& Hoffeins, 2013). The Gondwanan distribution of Hydropeza implies an even older minimum age (see below).

The Ragadinae includes the genera: Dipsomyia Bezzi, Hormopeza Zetterstedt, Hydropeza Sinclair, Ragas Walker, and Zanclotus Wilder (Sinclair, 1999; Sinclair \& Cumming, 2006). Only Hydropeza and Hormopeza are recorded from Australia (Sinclair, 1995).

Etymology. The type genus, Ragas (gender feminine) is

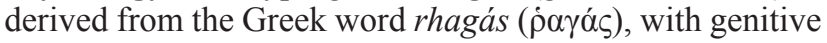
rhagádos (Latin rhagadis), which in medicine refers to fissures or cracks in the skin. It is not obvious what its meaning might have in common with the fly named by Walker. Given the Greek source of the generic name, the stem of Ragas is ragad- and consequently the subfamily is Ragadinae (Ulrich, pers. comm.).

\section{Genus Hydropeza Sinclair}

Hydropeza Sinclair, 1999: 135. Type-species: Hydropeza longipennae (Miller).

Diagnosis. This genus can be identified using the key to subfamilies and genus groups in Sinclair (2011), characterized by its long and apically rounded cell cua, pterostigma absent (Fig. 28), pubescent eyes (Fig. 13), fore coxa with spine-like setae (Fig. 14), bare laterotergite and recurved labrum (Figs 1, 3-6, 13).

Description. See Sinclair (1999) for description, with the following addition: male cercus undivided and continuous posteromedially with subepandrial sclerite or often subdivided into short anterior lobe and short to elongate posterior lobe (often termed clasping cercus); posterior cercus medially continuous with subepandrial sclerite.

Remarks. There are 11 described species of Hydropeza from New Zealand and Chile (Fig. 30) (Sinclair \& McLellan, 2004; Sinclair \& Plant, 2008). This study builds on these studies and describes the nine species from Australia. In a preliminary phylogenetic analysis, the $H$. longipennae-group of New Zealand was assigned as sister to the remaining species of the genus. The remaining New Zealand species were assigned to a monophyletic clade (Sinclair \& McLellan, 2004). The phylogeny of the Hydropeza is reanalysed in this study (see below).

\section{Key to Australian species of Hydropeza}

Most females from Queensland are not readily identifiable due to similar terminalia and uncertainty concerning variation. More study on positively associated females from Queensland is required.

$1 \quad$ Wings reduced to halter-like appendages; head and body chaetotaxy greatly reduced and slender; eyes closely approximated below antennae (Figs 1, 3) H. aptera sp. nov.

Wings fully developed; head and body chaetotaxy very long and bristle-like (Figs 4-6); eyes widely separated below antennae

2 Acrostichal setae present posterior to first pair of dorsocentral setae (females not readily distinguishable in the following species)

Acrostichal setae confined anteriorly to first pair of dorsocentral setae

3 Male cercus unforked; phallus inflated with highly modified apex comprised of lobes and jagged edges (Fig. 24); female abdominal segment 8 distinctly swollen H. intricata sp. nov.

Male cercus forked; phallus flattened with simple apex; female segment 8 not swollen 4

$4 \quad$ Male cercus U-shaped; upper branch straight with apex rounded (Fig. 23) H. divaricata sp. nov.

Male cercus V-shaped; upper branch slightly twisted with narrow apex (Fig. 12) H. curvata sp. nov. 
5 Arista-like stylus subequal to or longer than length of postpedicel; male hind femur swollen, wider than mid femur (as in Fig. 4), slender in female; hind tarsomere 4 unmodified in both sexes, not laterally compressed

Arista-like stylus shorter than length of postpedicel; hind femur slender in both sexes, not broader than other femora (Figs $5,6)$; hind tarsomere 4 laterally compressed in both sexes, with ventral keel

6 Disc of scutellum with numerous long setulae; male cercus Y-shaped, apex of surstylus with straight spine-like projection; postgonite digitiform, erect and extending beyond margin of epandrium (Fig. 25)

H. queenslandensis sp. nov.

Disc of scutellum with at most 1-2 pairs of long setulae; male terminalia otherwise

$7 \quad$ Arista-like stylus 2.5 times length of postpedicel; male cercus unforked, lying horizontally on epandrium, apex bent medially at right angle; apex of surstylus strongly rounded with stout setae on inner face; postgonite short, broad and truncate (Fig. 9) H. angulata sp. nov.

Arista-like stylus only slightly longer than postpedicel; male cercus antler-like, lower branch shorter than upper; apex of surstylus strongly hooked and arched anteromedially; postgonite sickle-shaped and hooked (Fig. 11) H. cornuta sp. nov.

8 Large species, wing at least $6 \mathrm{~mm}$ long (Fig. 5); face with row of long setulae on inner margin of eye (Fig. 13); scutellum with setae confined to margin; male foreleg with tarsomere 1 unmodified; male mid femur modified with knob-like ventral process (Fig. 15) H. tasmanica sp. nov.

Smaller species, wing less than $4 \mathrm{~mm}$ long (Fig. 6); face lacking setulae; scutellum with setulae dorsally on disc; male foreleg modified with claw-like process on tarsomere 1 (Fig. 18); male mid femur without knob-like ventral process H. unguicula sp. nov.

\section{Hydropeza angulata sp. nov.}

Figs 7, 9

Type material. Holotype $\hat{\sigma}$, labelled: “AUST: N.QLD:/ $31.6 \mathrm{~km} / \mathrm{up}$ Mt. Lewis Rd., 860m/ 21.iv.1994, cascading/

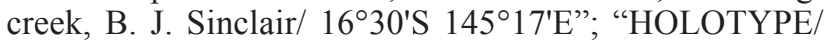
Hydropeza/ angulata/ Sinclair [red label]" (AMS). Paratypes: Queensland: $1 \widehat{\jmath}, 2$ 2 $9,14.7 \mathrm{~km}$ up Mt. Lewis Rd., $860 \mathrm{~m}$, 22.iv.1994, cascading ck, $16^{\circ} 30^{\prime} \mathrm{S} 145^{\circ} 17^{\prime} \mathrm{E}$, B. J. Sinclair (CNC); $1 \bigcirc^{\lambda}, 4$ 우, same data as holotype (AMS).

Diagnosis. This species is distinguished from other Queensland species by acrostichal setae confined anteriad of an imaginary line connecting the first (anteriormost) dorsocentral setae; arista-like stylus $2.5 \times$ length of postpedicel; male scutellum with $0-1$ pair of elongate discal setae; male mid femur with row of short basal posteroventral setae and mid tibia with short row of spine-like setae on apical third; male hind trochanter without spine-like anteroventral setae; and male cercus unbranched, with apex bent at right angle medially. Females are distinguished from all other species by discal setae mostly absent on the scutellum and segment 8 generally retracted within the abdomen and flattened.

Description. Head and abdomen dark brown, thorax brown with paler patches; coxae brownish yellow, legs progressively darker towards tips. Wing length 4-4.2 mm.

Male. Head. Ocellar setae very long, erect, divergent, inserted posterior to anterior ocellus; ocellar tubercle with some long setulae; postocellar seta stout and dark; upper postocular setae stout and dark, lower setae fine and slender; postgenal setae similar to lower postoculars. Face without setulae. Scape, pedicel and inner base of postpedicel slightly paler than remaining postpedicel; scape short and slender, slightly longer than length of globular pedicel; postpedicel not greatly prolonged, less than $2 \times$ longer than scape, basal portion elongate-oval, $2 \times$ longer than tapered apical portion; arista-like stylus $2.5 \times$ longer than postpedicel, concolorous with postpedicel. Proboscis stout and robust, extended beyond mid-length of fore coxa, directed posteriorly; palpus half-length of proboscis, clothed in long pale and dark setae; apex of palpus rounded; apical third of palpus flattened with dense pubescence.

Thorax. Clothed in fine pruinescence; mesonotum brown, with postpronotal lobe, lateral margin and postalar ridge pale brown; pleura paler than notum, pale along sutures. Setae generally long and stout; $2-4$ acrostichal setulae confined anterior to 1 st dorsocentral setae, less than $0.5 \times$ length of dc; pprn with 1 seta and 1-2 short setulae; 1 long presut spal; 5 uniserial dc, about subequal in length with several setae interspersed; 3 npl; 1 long psut spal and several shorter anterior setae; 1 pal seta and $1-2$ pale setulae; 1 pair of sctl, 


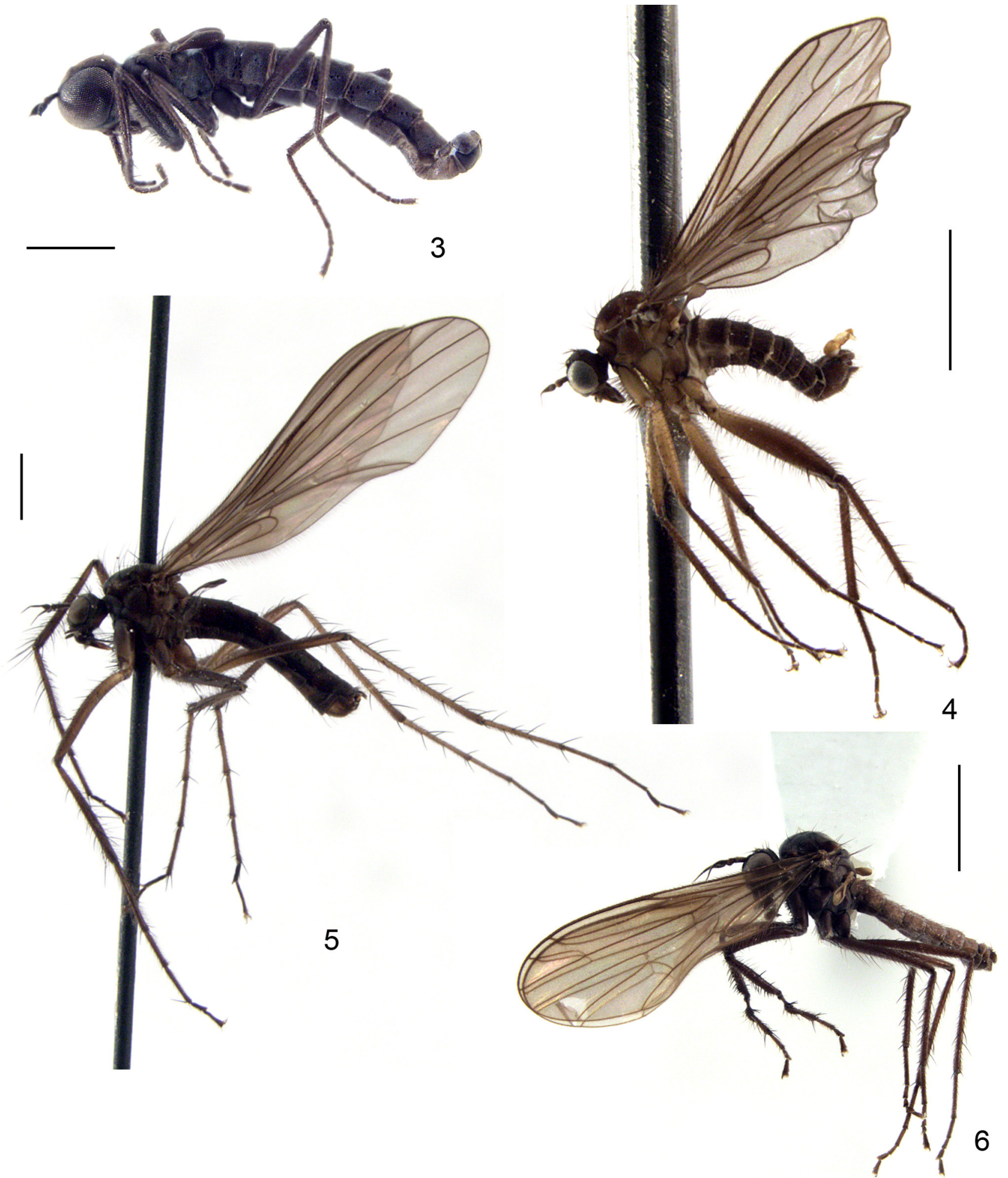

Figures 3-6. Habitus images of dried mounted male species of Hydropeza, lateral view. (3) H. aptera. (4) H. intricata. (5) H. tasmanica. (6) H. unguicula. Scale bars $=1.0 \mathrm{~mm}$, except Fig. 3 where scale bar $=0.5 \mathrm{~mm}$.

with 1 pair of finer outer marginal setae; disc of scutellum with 0-1 pair of long setae. Antepronotum with pair of pale setulae.

Legs. Coxae and femora ventrally yellowish-brown; remaining segments increasingly darker apically. Inner anterior margin of fore coxa with some 15-20 dark, variously lengthened and thickened spine-like setae, mostly concentrated apically; basal most seta longer than width of coxa. Anterior surface of mid and hind coxae with long brown setae. Legs clothed in very long setae as typical for genus, especially ventral faces. Fore femur straight, inflated (subequal in thickness to mid femur), with row of 2 stout anterior setae at apical fifth; 4-6 posterodorsal setae, apical 2 setae distinctly stouter. Fore tibia with 3 anteroventral setae on apical third; 2 anterodorsal and 2 posterodorsal setae; 1 anterodorsal preapical seta. Fore tarsomere 1 with 1 basal anteroventral and 1 preapical anterovental seta, more than $2 \times$ width of segment; 


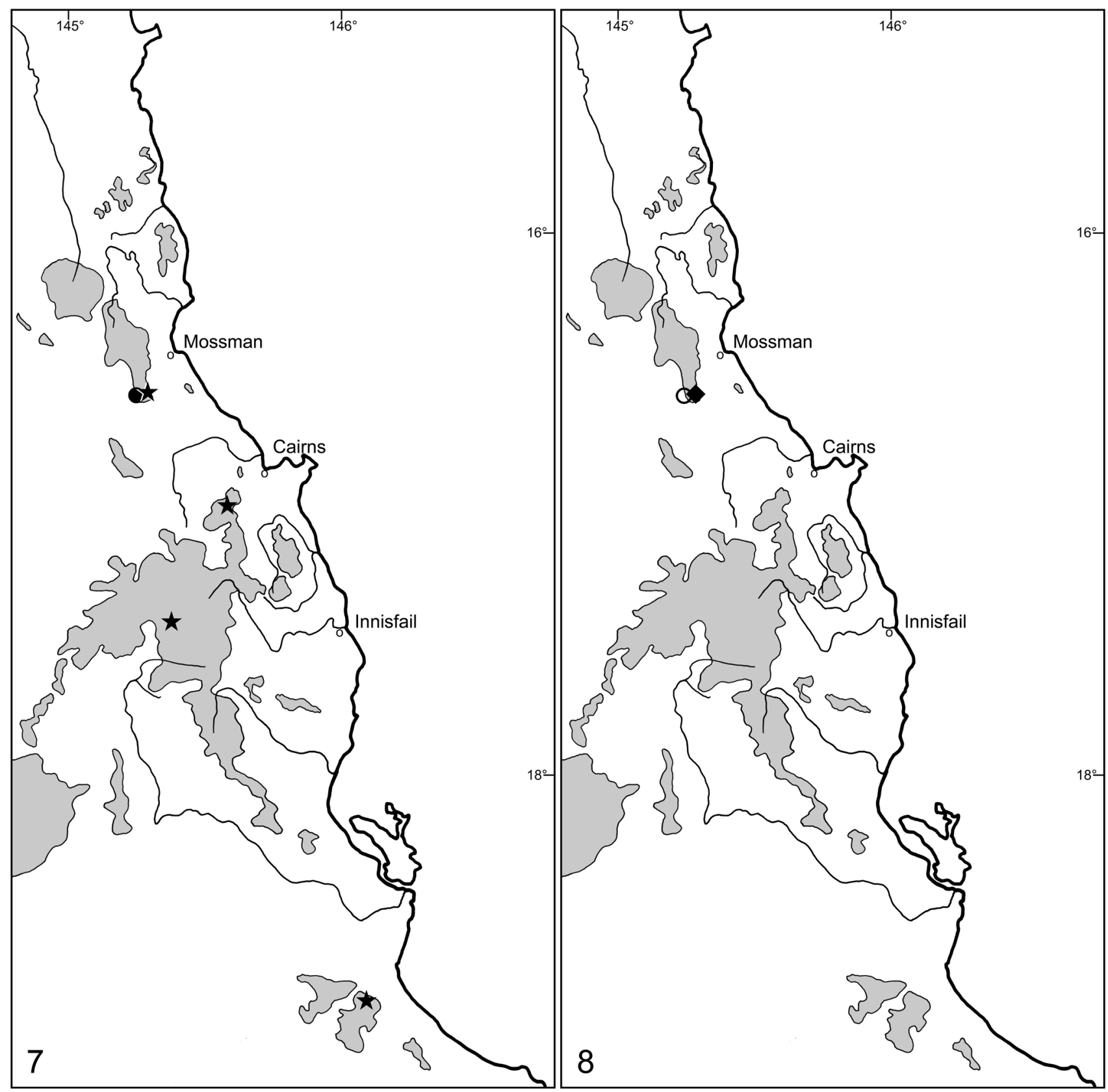

Figures 7-8. Known distribution of the Hydropeza species: (7) H. angulata; (•), H. queenslandica; ( $\star$ ); (8) H. cornuta; (O), and H. curvata; $(\diamond)$. Shaded areas indicate land above $700 \mathrm{~m}$ in altitude.

1 long basal ventral, 2-4 shorter ventral setae at middle and apex. Mid femur with row of 4 anterodorsal setae stouter towards apex; 1 anterior and 2 posterodorsal setae on apical third; basal half with row of 7-10 short, stout posteroventral setae, less than width of femur; apex with 1 anterior, 1 dorsal and 1 posterior preapical seta. Mid tibia with width reduced on ventral apical third, with row of 9-11 short spine-like setae; apex with 1 short, spur-like ventral and anterodorsal seta; 1 anterodorsal and 2 posterodorsal setae; apex with 1 dorsal seta. Mid tarsomere 1 with 1 long anteroventral and 1 posteroventral basal seta; apex with several preapical setae. Hind femur greatly inflated, nearly $2 \times$ broader than fore or mid femora, without erect dorsal setae; with anteroventral row of stout setae along apical third; apical fourth with 2-6 anterodorsal, $1-2$ posterodorsal, 1 anterior and 1 posterior seta.
Hind trochanter without spine-like anteroventral setae. Hind tibia with 1 anterodorsal, 1 anteroventral and 1 posterodorsal seta; 1 preapical anterodorsal and 1 apical anteroventral seta; apical fourth with dense posterior setae. Hind tarsomere 1 without erect setae. Fore and mid tarsomeres slightly longer than tibia; ventral apical margin of tarsomere 4 of fore and midlegs somewhat pale, flattened and expanded; tarsomere 4 and apical third of tarsomere 3 of hindleg slightly laterally compressed ventrally; tarsomere 5 of each leg lacking dorsoapical extension.

Wing. Infuscate with 1 long basal costal seta, longer than sctl; all veins lacking setulae; $\mathrm{R}_{4}$ and $\mathrm{R}_{5}$ distinctly divergent apically; bm-m complete; cell $\mathrm{dm}$ truncate, longer than cell $\mathrm{bm} ; \mathrm{CuA}+\mathrm{CuP}$ reduced to streak. Halter brown.

Abdomen. Tergites and sternites clothed in setae; setae 


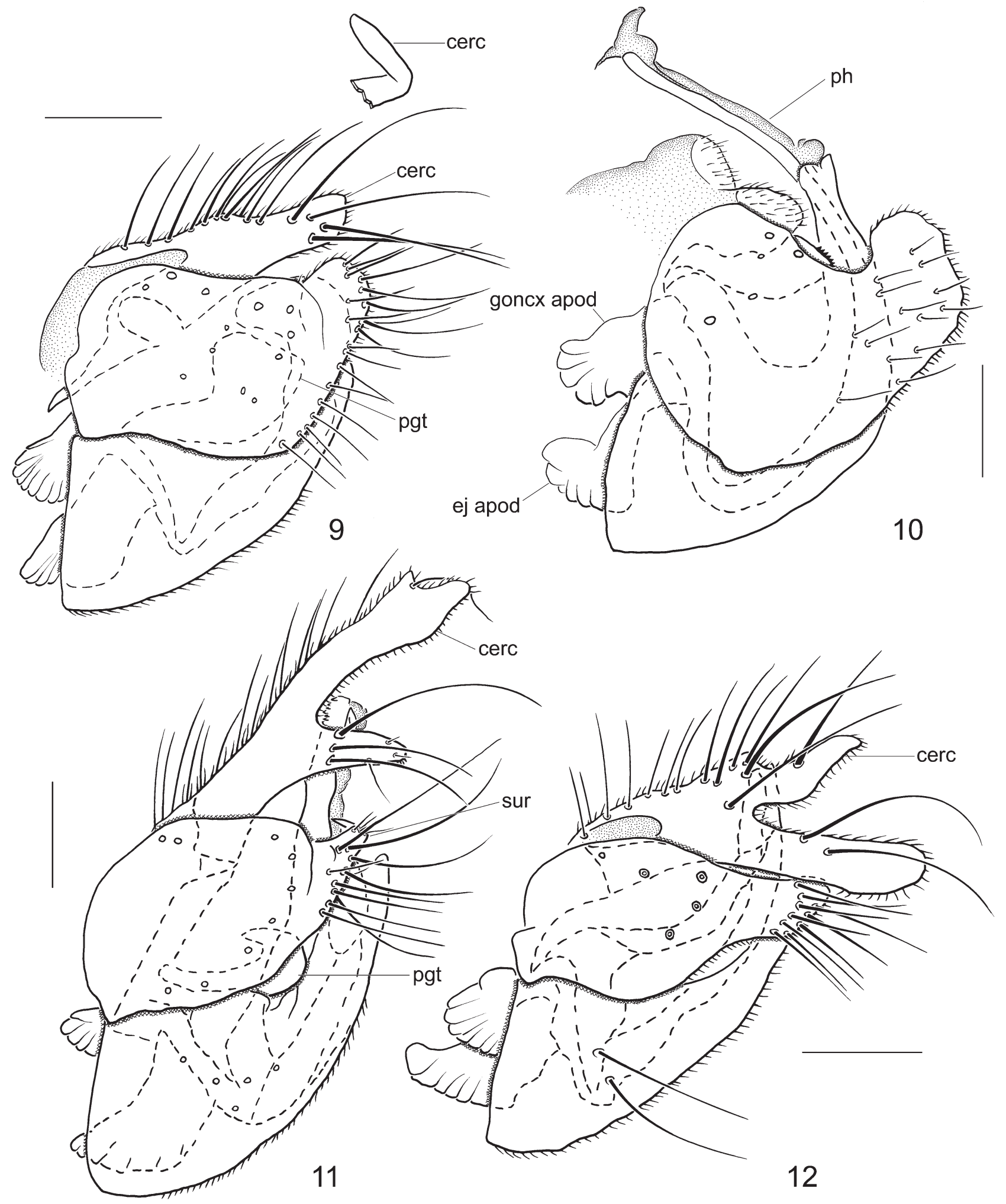

Figures 9-12. Male terminalia of Hydropeza, lateral view. (9) H. angulata (inset showing inner apex of cercus). (10) H. aptera. (11) H. cornuta. (12) H. curvata. Abbreviations: cerc, cercus; ej apod, ejaculatory apodeme; goncx apod, gonocoxal apodeme; pgt, postgonite; ph, phallus; sur, surstylus. Scale bars $=0.1 \mathrm{~mm}$. 

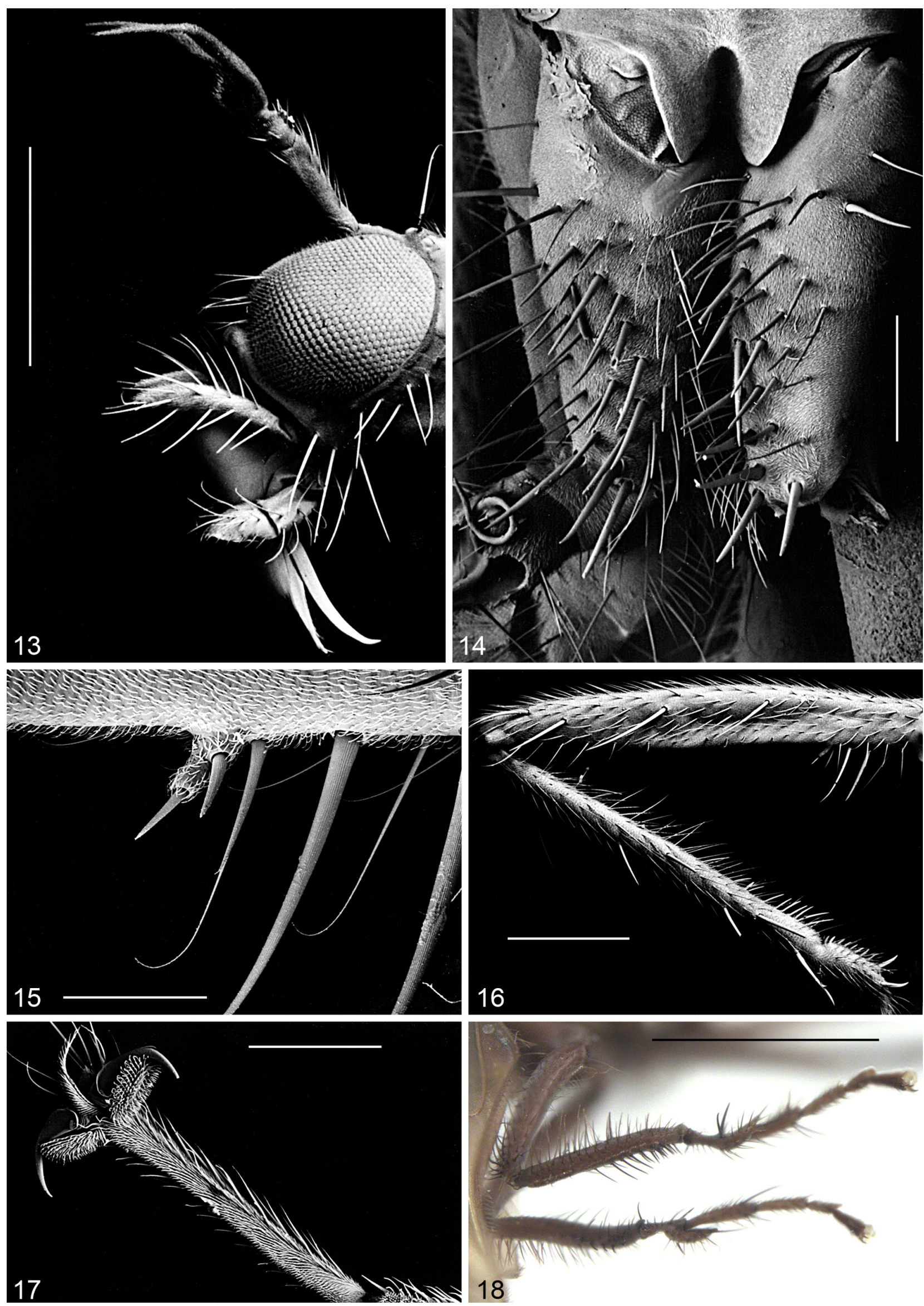

Figures 13-18. Scanning electron photographs of Hydropeza tasmanica and digital image of foreleg of H. unguicula. (13) Head (scale bar $=0.5 \mathrm{~mm}$ ) (from Sinclair \& McLellan, 2004, fig. 10). (14) Fore coxae (scale bar =0.2 mm). (15) Male mid femur (scale bar $=0.1 \mathrm{~mm}$ ). (16) Male mid femur and tibia (scale bar =0.5 mm). (17) Tarsomere 5 and acropod (scale bar $=0.2 \mathrm{~mm}) .(18)$ Male forelegs of $H$. unguicula $($ scale bar $=1.0 \mathrm{~mm}$ ). 


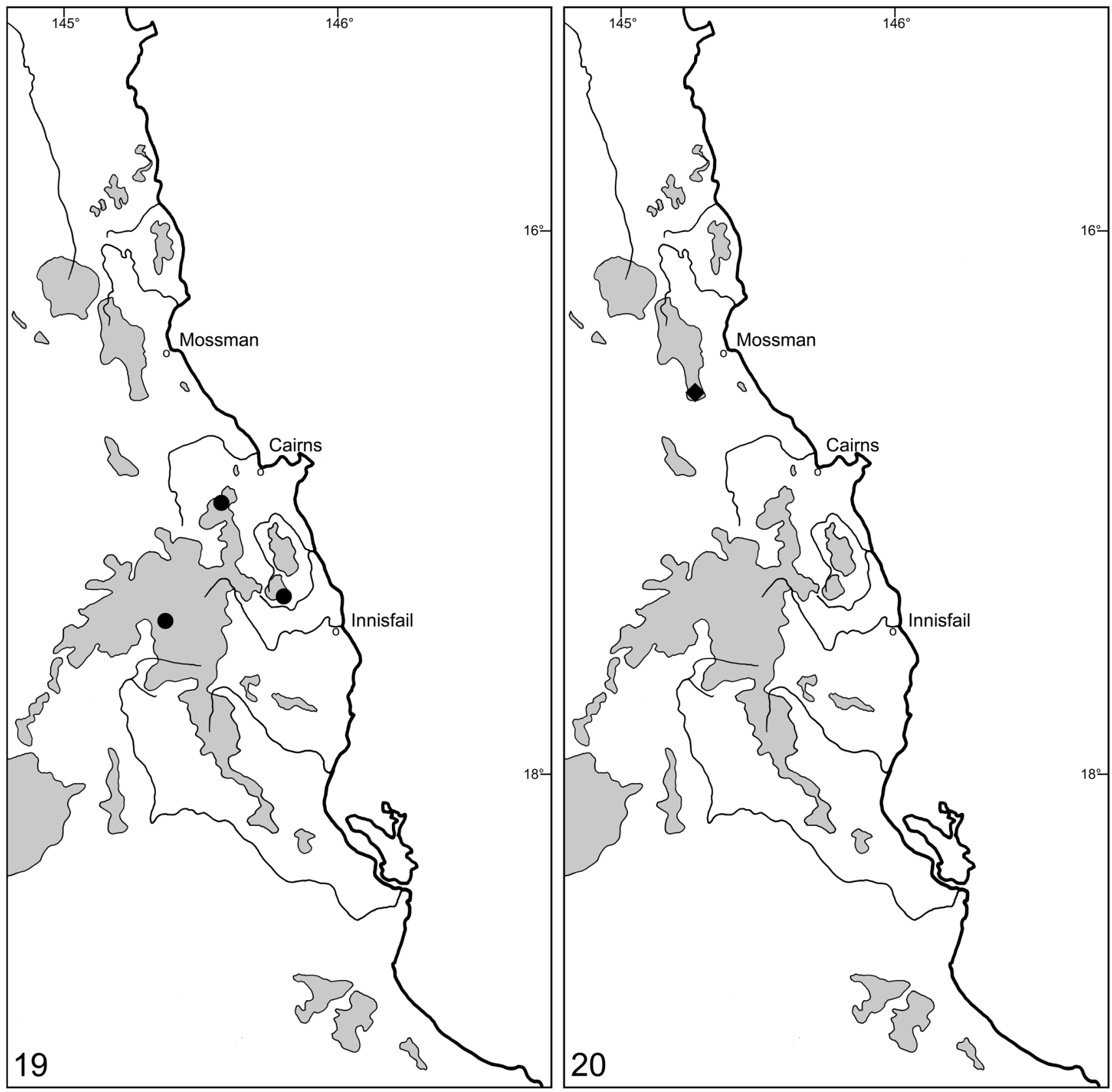

Figures 19-20. Known distribution of the Hydropeza species: (19) H. divaricata sp. nov. (•) and (20) H. intricata sp. nov. ( ). Shaded areas indicate land above $700 \mathrm{~m}$ in altitude.

of posterior margin overlapping more than half length of following tergite. T8 broad, nearly one-half length of T7; posterior marginal setae slender, some $1.5 \times$ length of tergite.

Terminalia (Fig. 9). Cercus projected horizontally, shorter than epandrium, not forked or subdivided; apex sharply bent at right angle medially, nearly touching opposing cercus. Epandrium broad with scattered setae. Surstylus short, with broadly rounded apex, not arched medially; inner margin with cluster of some 8 stout setae. Hypandrium subrectangular broad; apical margin not notched; gonocoxal apodeme broad, rounded; postgonite broad, short and L-shaped, touching opposing postgonite medially. Phallus broad with apex inflated; ejaculatory apodeme straight, longer than gonocoxal apodeme.
Female. Similar to male except as follows: scutellum with 1 pair of discal setae; mid femur lacking row of stout posteroventral basal setae; mid tibia not narrowed apically, lacking row spine-like setae; hind femur not strongly inflated, lacking anteroventral row of stout setae. Terminalia (not dissected): segment 8 not inflated, broad; cercus slightly longer than epiproct, nearly $2 \times$ longer than wide; broad with rounded apex.

Distribution. This species is recorded from above $800 \mathrm{~m}$ on Mt. Lewis, Queensland (Fig. 7).

Etymology. The specific name is from the Latin angulatus (with angles), in reference to the right angle bend of the male cercus. 


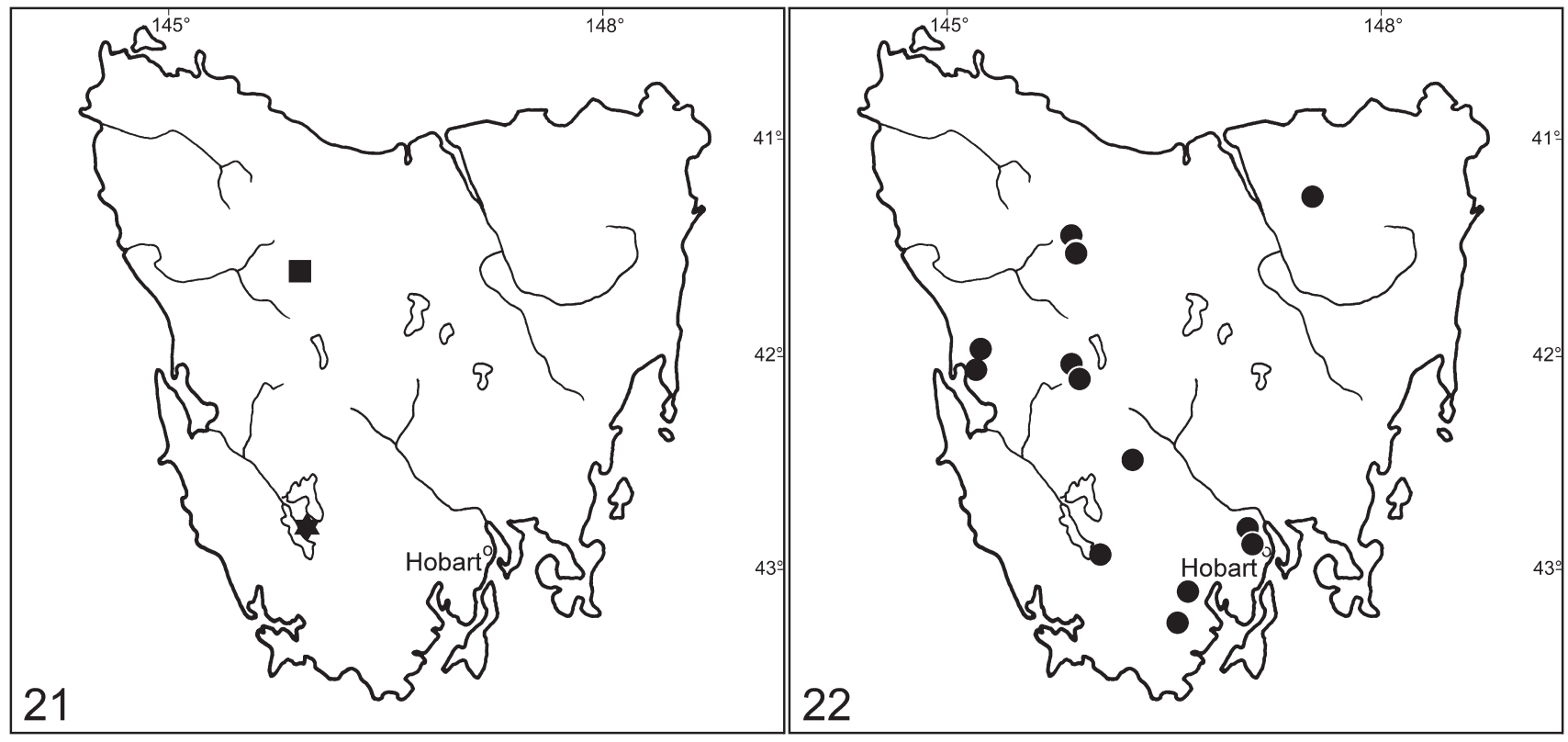

Figures 21-22. Known distribution of the new Hydropeza species: (21) H. aptera sp. nov. ( ); H. unguicula sp. nov. ( $\mathbf{\square}$ ); and (22) H. tasmanica sp. nov. (•).

\section{Hydropeza aptera sp nov.}

Figs 1-3, 10, 21

Type material. Holotype $\hat{\delta}$, labelled: "TAS: McPartlan Pass, / 42 $51^{\prime} \mathrm{S} 146^{\circ} 11^{\prime} \mathrm{E} /$ pitfall ARE(Y); 17./ viii.1999; M. Driessen"; "HOLOTYPE/ Hydropeza/ aptera/ Sinclair [red label]" (AMS). Paratypes: Tasmania: $1 \hat{0}$, same data as holotype, except ARE(Y)4, 14.ix.1999 (AMS); 1ㅇ, same data as holotype, except ARE(Y)8, 28.vii.1999 (AMS); $2 \hat{\jmath} \widehat{\partial}$, McPartlan Pass, buttongrass moorland, 28.vii.1999, pitfall tp, TRW6, 42 $51^{\prime} 12^{\prime \prime S} 146^{\circ} 12^{\prime} 39^{\prime \prime} \mathrm{E}, 320 \mathrm{~m}$, M. Driessen (CNC); 19, ditto, except TRE(0) 16.v.2000 (CNC); 10,, 4 우우, Airstrip Rd, sites 1A-6P, 4251'5"S 146¹1'24"E,

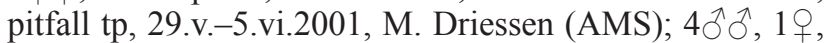
ditto, except ARE(Y), 4250'30"S 146²14'36"E, 320 m, M. Driessen (AMS, CNC).

Diagnosis. This is the only apterus species of Hydropeza, with the wings reduced to halter-like appendages and legs and scutum with reduced chaetotaxy.

Description. Head and thorax dark brown to black with greyish pruinescence, abdomen brown to black with thin pruinescence; legs dark brown. Wing appendage length $0.3-0.4 \mathrm{~mm}$.

Male. Head. Oval, produced posterodorsally, somewhat flattened dorsally. Ocellar setae short, erect, divergent, inserted between posterior and anterior ocelli; ocellar tubercle with some short setulae; postocellar and postocular setae short and slender; postgenal setae pale, slender, longer than postocellar setae. Face very narrow, closely approximated, lacking setulae. Scape short and slender, subequal in length to pedicel; postpedicel pointed-ovate, longer than scape and pedicel combined, with very short knob-like apical stylus. Proboscis stout and robust, short, extended well beyond mid-length of fore coxa, directed posteriorly; palpus very short, oval about $0.15 \times$ length of proboscis, clothed in pale setae; apex of palpus rounded.
Thorax. Greatly shortened and reduced due to apterus condition. Clothed in fine pruinescence; mesonotum with chaetotaxy reduced; scutellum shorted with pair of short, pale apical setae.

Legs. Brown, fore coxa with fine pruinescence, similar to thorax. Inner anterior margin of fore coxa with some 20 dark spine-like setae, mostly concentrated apically and mid-basally; setae not longer than width of coxa. Anterior surface of mid and hind coxae with long brown setae. Legs lacking long, fine setae. Fore femur distinctly broader than mid and hind femora; basal third with 4 long posteroventral setae, longer than femur width; anteroventral face with fine, pale setae. Fore tibia with 4 anteroventral, 2 posteroventral spine-like setae. Fore tarsomere 1 with 4 anteroventral and 4 posteroventral stout setae, anteroventral setae nearly twice longer than posteroventral setae. Mid femur with 4-5 posteroventral setae, nearly as long as width of femur; anteroventral row of short, spine-like setae along entire length. Mid tibia lacking distinct erect setae. Mid tarsomere 1 lacking distinct setae. Hind femur with erect dorsal setae; 1 preapical anterior, 2-3 preapical anteroventral setae. Hind tibia with 1 stout preapical anteroventral seta. Hind tarsomere 1 with biserial row of ventral setae. Tarsomeres of hindleg much longer than tibia; ventral apical margin of tarsomere 4 of fore and midlegs not flattened and expanded; tarsomere 4 of hindleg not laterally compressed ventrally; tarsomere 5 of each leg lacking dorsoapical extension.

Wing. Reduced to halter-like appendage; concolorous with thorax. Halter absent.

Abdomen. Tergites and sternites with short, sparse setae; marginal setae not lengthened. T8 broad, more than half length of T7; setae similar to preceding segments.

Terminalia (Fig. 10). Cercus divided into subrectangular, thinly sclerotized anterior section, bearing short setae; posterior cercus broadly sclerotized medially, with apical row of peg-like setae on either side of distinct median notch. Epandrium small, oval; lamellae separated dorsally beneath cercus by wide membranous gap. Surstylus short, broad and 
truncate apically, clothed in fine setae only. Hypandrium keel-like, prolonged dorsally into phallic guide; gonocoxal apodeme small, rounded; apex of hypandrium flattened and broad surrounding emerging phallus; postgonites appear fused to apex of hypandrium. Phallus strongly arched at base, tapered to slender recurved tip; ejaculatory apodeme small, apical margin expanded.

Female. Similar to male except as follows: stout setae on fore and midlegs longer and more pronounced. T10 divided medially. Cercus short and rounded apically, slightly longer than width, shorter than length of tergite 10 .

Distribution. This species is restricted to Tasmania (Fig. 21), currently known only from the type-locality and apparently active in cold months, from May to September [minimum temperature: July $3.2^{\circ} \mathrm{C}$ (Dreissen et al., 2013)].

Etymology. The specific name is derived from the Greek apteros (wingless), referring to the virtual absence of wings in this species.

Remarks. All specimens were collected in pitfall traps set out in buttongrass moorland (Fig. 2), which at this location has a shrubby element (Myrtaceae, Epacridaceae) as well as monocots (Cyperaceae and Restionaceae) dominated by buttongrass (Driessen et al., 2013). The habitat at approximately $320 \mathrm{~m}$ includes many standing pools and riddled with water-filled crayfish burrows (Driessen, pers. comm., 2014). Small streams run through the plains and large lakes occur nearby. In addition, the waters are highly acidic (around pH 4). A montane moorland site (Lake St. Clair, approx. $800 \mathrm{~m}$ ) was also surveyed by Driessen et al. (2013), but these flightless empidids were not collected.

Wingless or flightlessness among Empidoidea is possibly an adaptation for increased running ability among secretive habitats such as the grasses of the moorland and/or an adaptation to cold conditions which make thermoregulation of thoracic flight muscles difficult (Hackman, 1964; Bickel, 2006). Included among the pitfall trap samples from McPartlan Pass was another wingless empidoid, Apterodromia tasmanica Sinclair \& Cumming (Hybotidae: Ocydromiinae). This latter species was originally known from litter samples, collected in January and March (Sinclair \& Cumming, 2000). Ground predation, particularly from ants has been cited as a major factor limiting wider development of flightlessness in Diptera (Bickel, 2006). However, ant abundance was only lower during the cold months compared to warm months at this lowland moorland (Driessen et al., 2013, fig. 1).

\section{Hydropeza cornuta sp. nov.}

\section{Figs 8,11}

Type material. Holotype $\delta^{1}$, labelled: "AUST: N.QLD:/ 31.6km/ up Mt. Lewis Rd., 1000m/21.iv.1994, cascading/

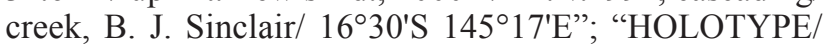
Hydropeza/ cornuta/ Sinclair [red label]" (AMS). Paratypes: Queensland: $1{ }^{\lambda}, 14.7 \mathrm{~km}$ up Mt. Lewis Rd., $860 \mathrm{~m}$, 22.iv.1994, cascading ck, $16^{\circ} 30^{\prime} \mathrm{S} 145^{\circ} 17^{\prime} \mathrm{E}, \mathrm{B}$. J. Sinclair (CNC); 10, 25 km up Mt. Lewis Rd., 1000 m, 22.iv.1994, roadside pools, $16^{\circ} 32^{\prime} \mathrm{S} 145^{\circ} 17^{\prime} \mathrm{E}$, B. J. Sinclair (CNC); $7 ठ ึ, 31.6 \mathrm{~km}$ up Mt. Lewis Rd., $1000 \mathrm{~m}, 21 . i v .1994$, cascading ck, $16^{\circ} 30^{\prime} \mathrm{S} 145^{\circ} 17^{\prime} \mathrm{E}, \mathrm{B}$. J. Sinclair (AMS, CNC).
Diagnosis. This species is distinguished from other Queensland species by acrostichal setae confined anteriad of an imaginary line connecting the first (anteriormost) dorsocentral setae; male scutellum with at most 1-2 pairs of elongate discal setae; male mid femur with short row of basal posteroventral setae and mid tibia with short row of spine-like setae on apical third; male hind trochanter with spine-like anteroventral seta; and male cercus long, projecting and antler-like.

Description. Head and abdomen dark brown, thorax brown with paler patches; coxae brownish yellow, legs progressively darker towards tips. Wing length $2.6-3 \mathrm{~mm}$.

Male. Head. Ocellar setae very long, erect, divergent, inserted posterior to anterior ocellus; ocellar tubercle with some long setulae; postocellar seta stout and dark; upper postocular setae stout and dark, lower setae fine and slender; postgenal setae similar to lower postoculars. Face without setulae. Scape and pedicel slightly paler than postpedicel; scape short and slender, slightly longer than length of globular pedicel; postpedicel not greatly prolonged, more than $3 \times$ longer than scape, basal portion elongate-oval, slightly longer than slender, straight apical portion; arista-like stylus distinctly longer than postpedicel, concolorous with postpedicel. Proboscis stout and robust, extended beyond mid-length of fore coxa, directed posteriorly; palpus halflength of proboscis, clothed in long pale and dark setae; apex of palpus rounded; apical third of palpus somewhat flattened with dense pubescence.

Thorax. Clothed in fine pruinescence; mesonotum brown, with postpronotal lobe, lateral margin and postalar ridge pale brown; pleura paler than notum, pale along sutures. Setae generally long and stout; 2-3 acrostichal setulae confined anterior to 1 st dorsocentral seta, less than $0.5 \times$ length of dc; pprn with 1 seta and several short setulae; 1 long presut spal; 5-6 uniserial dc, about subequal in length; $3 \mathrm{npl} ; 1$ long psut spal and 1-2 finer setae; 1 pal seta; 1 pair of sctl, with 1-2 pairs of finer outer marginal setae; disc of scutellum with 1-2 pairs of long setae. Antepronotum with pair of pale setulae.

Legs. Coxae and femora ventrally yellowish-brown; remaining segments increasingly darker apically. Inner anterior margin of fore coxa with some 15-20 dark variously lengthened and thickened spine-like setae, mostly concentrated apically; basal most seta longer than width of coxa. Anterior surface of mid and hind coxae with long brown setae. Legs clothed in very long setae as typical for genus, especially ventral faces. Fore femur straight, inflated (subequal in thickness to hind femur), with row of 2 stout anterior setae at apical fifth; 5-7 posterodorsal setae, stouter towards apex. Fore tibia with 2 anteroventral setae on apical third; 2 anterodorsal and 2 posterodorsal setae; 1 anterodorsal and 1 ventral preapical seta. Fore tarsomere 1 with 1 basal anteroventral and 1 preapical anterovental seta, more than $2 \times$ width of segment; 1 long basal ventral and 2 shorter ventral setae on basal half. Mid femur with row of 5-6 anterodorsal setae, stouter towards apex; 1 anterior, 1 dorsal and 1 posterior seta on apical third; basal half with row of 4-5 stout posteroventral setae; apex with 1 anterior and 1 posterior preapical seta. Mid tibia with width reduced on ventral apical third, with row of 5 short spine-like setae; apex with short spur-like ventral seta; 1 anterodorsal and 1 posterodorsal seta near mid-length; 1 basal posterodorsal seta; apex with 1 dorsal and 1 posterior seta. Mid tarsomere 1 with 1 long 


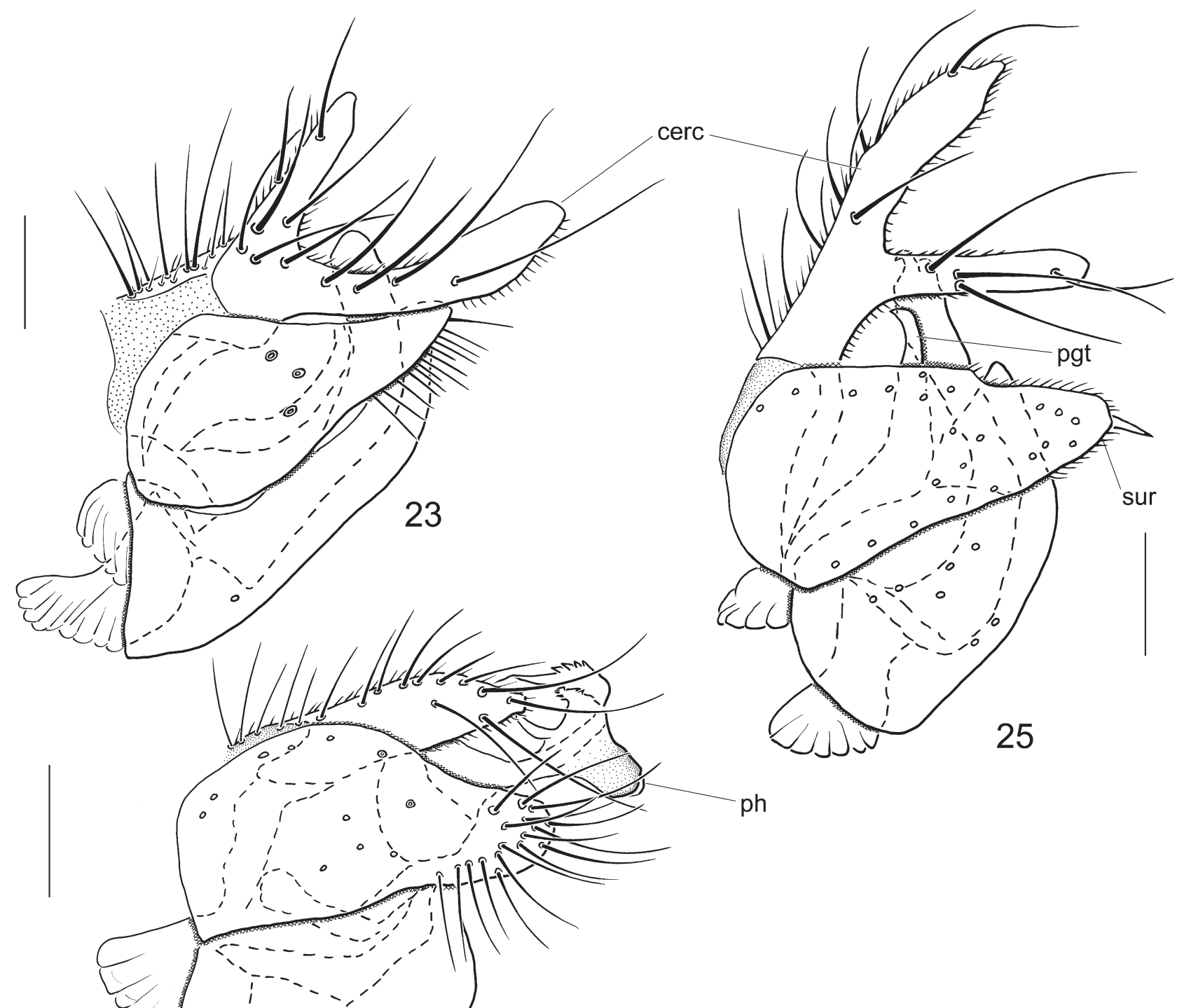

Figures 23-25. Male terminalia of Hydropeza, lateral view. (23) $H$. divaricata. (24) H. intricata. (25) H. queenslandensis. Abbreviations: cerc, cercus; $p h$, phallus; pgt, postgonite; sur, surstylus. Scale bars $=0.1 \mathrm{~mm}$.

anteroventral basal seta. Hind femur inflated, subequal in thickness to fore femur, without erect dorsal setae; with anteroventral row of stout setae along entire length; apical fourth with 2 anterodorsal, 1 posterodorsal, 1 anterior and 1 posterior seta. Hind trochanter with spine-like anteroventral seta. Hind tibia with 2 anterodorsal, 1 anteroventral and 4-5 posterodorsal setae; 1 preapical anterodorsal and 1 apical anteroventral seta; apical fourth with dense posterior setae. Hind tarsomere 1 without erect setae. All tarsomeres longer than tibia; ventral apical margin of tarsomere 4 of fore and midlegs somewhat pale, flattened and expanded; tarsomere 4 of hindleg not laterally compressed ventrally; tarsomere 5 of each leg lacking dorsoapical extension.

Wing. Infuscate with 1 long basal costal seta, longer than sctl; all veins lacking setulae; $\mathrm{R}_{4}$ and $\mathrm{R}_{5}$ distinctly divergent apically; bm-m complete; cell dm slightly produced, longer than cell bm; $\mathrm{CuA}+\mathrm{CuP}$ reduced to streak. Halter brown.

Abdomen. Tergites and sternites clothed in setae; setae of posterior margin overlapping more than half length of following tergite. T8 broad, nearly one-half length of T7; posterior marginal setae slender, some twice length of tergite.
Terminalia (Fig. 11). Cercus long, projected and antlerlike, deeply forked, U-shaped; apex of upper branch with broad notch and long seta, arched medially, $3 \times$ longer than lower branch; lower branch with rounded apex, bearing several long setae. Epandrium broad, tapered apically with long setae in vertical row. Surstylus strongly tapered, apex hook-shaped, strongly arched; posterior margin with row of stout setae. Hypandrium keel-like, not greatly prolonged; apical margin with deep medial notch; gonocoxal apodeme short, rounded; postgonite recurved, sickle-shaped. Phallus elongate, upright, broad, apically flattened and spoon-shaped; ejaculatory apodeme L-shaped, longer than gonocoxal apodeme.

Female. Unknown.

Distribution. This species is recorded from above $800 \mathrm{~m}$ on Mt. Lewis, Queensland (Fig. 8).

Etymology. The specific name is from the Latin cornutus (bearing horns, horned), in reference to the antler-shaped and upright projecting cerci. 


\section{Hydropeza curvata sp. nov.}

Figs 8,12

Type material. Holotype $\widehat{\partial}$, labelled: “AUST: N.QLD:/ $14.7 \mathrm{~km} /$ up Mt. Lewis Rd., $860 \mathrm{~m} / 22$. iv.1994, cascading/ creek, B. J. Sinclair/ 16³0'S 14517'E"; "HOLOTYPE/ Hydropeza/ curvata/ Sinclair [red label]" (AMS). Paratypes: Queensland: 6우, same data as holotype, 16, 22.iv.1994 (AMS, CNC); 19, $14.7 \mathrm{~km}$ up Mt. Lewis Rd., $860 \mathrm{~m}$, 15-16.iv.1994, ypans, stream, $16^{\circ} 30^{\prime} \mathrm{S} 145^{\circ} 17^{\prime} \mathrm{E}, \mathrm{B}$. J. Sinclair (CNC); $1 \hat{\circ}, 1$ ㅇ, 31.6 km up Mt. Lewis Rd., 1000 $\mathrm{m}, 21$.iv.1994, cascading ck, $16^{\circ} 30^{\prime} \mathrm{S} 145^{\circ} 17^{\prime} \mathrm{E}$, B. J. Sinclair (CNC).

Diagnosis. This species is distinguished from other Queensland species by acrostichal setae extending to prescutellar depression; male scutellum with at most a pair of elongate discal setae; male mid femur with short row of basal posteroventral setae and mid tibia with short row of spine-like setae on apical third; male hind trochanter without spine-like anteroventral setae; and male cercus deeply forked, V-shaped. Females are distinguished from all other species by numerous marginal setae on the scutellum and acrostichal setae extending to the prescutellar depression.

Description. Head and abdomen dark brown, thorax brown with paler patches; coxae brownish yellow, legs progressively darker towards tips. Wing length $3.2-3.6 \mathrm{~mm}$.

Male. Head. Ocellar setae very long, erect, divergent, inserted posterior to anterior ocellus; ocellar tubercle with some long setulae; postocellar seta stout and dark; upper postocular setae stout and dark, lower setae fine and slender; postgenal setae similar to lower postoculars. Face without setulae. Scape and pedicel slightly paler than postpedicel; scape short and slender, slightly shorter than length of globular pedicel; postpedicel not greatly prolonged, $2 \times$ longer than pedicel, basal portion elongate-oval, longer than slender, straight apical portion; arista-like stylus slightly longer than postpedicel, concolorous with postpedicel. Proboscis stout and robust, extended slightly beyond midlength of fore coxa, directed posteriorly; palpus about half length of proboscis, clothed in long dark setae; apex of palpus rounded; apical third of palpus flattened with dense pubescence.

Thorax. Clothed in fine pruinescence; mesonotum brown, with postpronotal lobe, lateral margin and postalar ridge pale brown; pleura paler than notum, pale along sutures. Setae generally long and stout; acrostichal setulae extending to prescutellar depression, less than $0.5 \times$ length of dc; pprn with 1 seta and several short setulae; 1 long presut spal; 5 uniserial dc, about subequal in length, with 2-3 intermixed nearly subequal setae; $3 \mathrm{npl} ; 1$ long psut spal and 1-2 finer setae; 1 pal seta; 1 pair of sctl, with 2 pairs of finer outer marginal setae; disc of scutellum with 1 pair of long setae. Antepronotum with pair of pale setulae.

Legs. Coxae and femora ventrally yellowish-brown; remaining segments increasingly darker apically. Inner anterior margin of fore coxa with some 15 dark, variously lengthened and thickened spine-like setae, mostly concentrated apically; basal most seta longer than width of coxa. Anterior surface of mid and hind coxae with long brown setae. Legs clothed in very long setae as typical for genus, especially ventral faces. Fore femur straight, inflated (narrower than hind femur), with row of 2 stout anterior setae at apical fifth; 5-6 posterodorsal setae, stouter towards apex. Fore tibia with 2 anteroventral setae on apical third; 2 anterodorsal and 2 posterodorsal setae; 1 anterodorsal preapical seta. Fore tarsomere 1 with 1 basal anteroventral and 1 preapical anterovental seta, more than $2 \times$ width of segment; 1 long basal ventral and 1 shorter ventral seta on basal third. Mid femur with 2-3 anterodorsal setae, 1 anterior seta and 1 posterodorsal seta on apical third; basal half with row of 3-4 stout posteroventral setae; apex with 1 anterior, 1 dorsal and 1 posterior preapical seta. Mid tibia with width reduced on ventral apical third, with row of 7-8 short spine-like setae; apex with short, spur-like ventral seta; 1 anterodorsal and 1 posterodorsal seta near mid-length; 1 basal posterodorsal seta; apex with 1 dorsal and 1 posterior seta. Mid tarsomere 1 with 1 long anteroventral basal seta. Hind femur inflated, nearly $2 \times$ broader than fore femur, without erect dorsal setae; with anteroventral row of stout setae along entire length; apical fourth with 2 anterodorsal, 1 anterior and 1 posterior seta. Hind trochanter without spine-like anteroventral setae. Hind tibia with 2 anterodorsal and 4-6 posterodorsal setae; 1 preapical anterodorsal and 1 apical anteroventral seta; apical fourth with dense posterior setae. Hind tarsomere 1 without erect setae. All tarsomeres longer than tibia; ventral apical margin of tarsomere 4 of fore and midlegs somewhat pale, flattened and expanded; tarsomere 4 of hindleg not laterally compressed ventrally; tarsomere 5 of each leg lacking dorsoapical extension.

Wing. Infuscate with 1 long basal costal seta, longer than sctl; all veins lacking setulae; $\mathrm{R}_{4}$ and $\mathrm{R}_{5}$ distinctly divergent apically; bm-m complete; cell $\mathrm{dm}$ produced apically, subequal in length to cell $\mathrm{bm} ; \mathrm{CuA}+\mathrm{CuP}$ reduced to faint streak. Halter pale brown.

Abdomen. Tergites and sternites clothed in setae; setae of posterior margin overlapping more than half length of following tergite. $\mathrm{T} 8 \mathrm{broad}$, one-third length of T7; posterior marginal setae slender, less than twice length of tergite.

Terminalia (Fig. 12). Cercus elongate and lying along dorsal edge of epandrium, deeply forked, V-shaped; upper branch slightly twisted, arched medially with narrow apex; lower branch longer than length of upper with broadly rounded apex. Epandrium round, tapered apically. Surstylus thumb-shaped, apex rounded; apical margin with numerous long setae. Hypandrium keel-like, not extended beyond surstylus; apical margin truncate without medial notch; gonocoxal apodeme short, rounded; postgonite digitiform, divergent with sharply attenuated apex. Phallus broad, apically flattened and spoon-shaped; ejaculatory apodeme L-shaped, longer than gonocoxal apodeme.

Female. Similar to male except as follows: scutellum with numerous marginal setae; mid femur lacking row of stout posteroventral basal setae; mid tibia not narrowed apically, lacking row of spine-like setae; hind femur not broader than mid femur, lacking anteroventral row of stout setae. Terminalia (not dissected): cercus slightly longer than epiproct, broad with rounded apex.

Distribution. This species is recorded from above $800 \mathrm{~m}$ on Mt. Lewis, Queensland (Fig. 8).

Etymology. The specific name is from the Latin curvatus (bend, bow, crook), in reference to slightly twisted upper branch of the male cercus. 


\section{Hydropeza divaricata sp. nov.}

Figs 19, 23

Type material. Holotype $\widehat{\partial}$, labelled: “AUST: N.QLD:/ Bellenden Ker N.P./ Bartle Frere Tr., 200m/ 12-21.iv.1994, malaise/ B. J. Sinclair/ $17^{\circ} 25^{\prime}$ S $145^{\circ} 51^{\prime} \mathrm{E}^{\prime}$; "HOLOTYPE/ Hydropeza/ divaricata/ Sinclair [red label]" (AMS). Paratypes: Queensland: $7 ð ð, 9$ 우, same data as holotype (AMS); 5

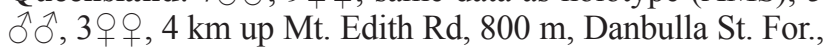
MT across ck, 22-27.iv.1994, $17^{\circ} 05^{\prime}$ S $145^{\circ} 38^{\prime}$ E, B. J. Sinclair

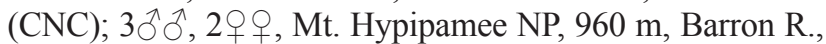
27.iv.1994, $17^{\circ} 26^{\prime}$ S $145^{\circ} 29^{\prime} \mathrm{E}$, B. J. Sinclair (CNC).

Diagnosis. This species is distinguished from other Queensland species by acrostichal setae extending posterior to (level of) second dorsocentral setae; male scutellum with at most a pair of elongate discal setae; male mid femur with short row of basal posteroventral setae and mid tibia with short row of spine-like setae on apical third; male hind trochanter without spine-like anteroventral setae; and male cercus deeply forked, U-shaped. Females are distinguished from all other species by 1-2 pairs of discal setae on the scutellum and acrostichal setae extending posterior to (level of) second dorsocentral setae.

Description. Head and abdomen dark brown, thorax brown with paler patches; coxae brownish yellow, legs progressively darker towards tips. Wing length $3.3-4 \mathrm{~mm}$.

Male. Head. Ocellar setae very long, erect, divergent, inserted posterior to anterior ocellus; ocellar tubercle with some long setulae; postocellar seta stout and dark; upper postocular setae stout and dark, lower setae fine and slender; postgenal setae similar to lower postoculars. Face without setulae. Scape and pedicel slightly paler than postpedicel; scape short and slender, slightly longer than length of globular pedicel; postpedicel not greatly prolonged, $3 \times$ longer than scape, basal portion elongate-oval, longer than slender, straight apical portion; arista-like stylus slightly longer than postpedicel, concolorous with postpedicel. Proboscis stout and robust, extended slightly beyond mid-length of fore coxa, directed posteriorly; palpus less than half length of proboscis, clothed in long pale setae; apex of palpus rounded; apical third of palpus somewhat flattened with dense pubescence.

Thorax. Clothed in fine pruinescence; mesonotum brown, with postpronotal lobe, lateral margin and postalar ridge pale brown; pleura paler than notum, pale along sutures. Setae generally long and stout; acrostichal setulae extending between 2 nd and 4th dorsocentral seta, less than $0.5 \times$ length of dc; pprn with 1 seta and several short setulae; 1 long presut spal; 5 uniserial dc, about subequal in length, with $2-3$ intermixed nearly subequal setae; $3 \mathrm{npl} ; 1$ long psut spal and 1-2 finer setae; 1 pal seta; 1 pair of sctl, with 2 pairs of finer outer marginal setae; disc of scutellum with 1 pair of long setae. Antepronotum with pair of pale setulae.

Legs. Coxae and femora ventrally yellowish-brown; remaining segments increasingly darker apically. Inner anterior margin of fore coxa with some 15-20 dark, variously lengthened and thickened spine-like setae, mostly concentrated apically; basal most seta longer than width of coxa. Anterior surface of mid and hind coxae with long brown setae. Legs clothed in very long setae as typical for genus, especially ventral faces. Fore femur straight, inflated (narrower than hind femur), with row of 2 stout anterior setae at apical fifth; 5-6 posterodorsal setae, stouter towards apex. Fore tibia with 2 anteroventral setae on apical third; 2 anterodorsal and 2 posterodorsal setae; 1 anterodorsal preapical seta. Fore tarsomere 1 with 1 basal anteroventral and 1 preapical anterovental seta, more than $2 \times$ width of segment; 1 long basal ventral and 1 shorter ventral seta on basal third. Mid femur with 2-3 anterodorsal setae, 1 anterior seta and 1 posterodorsal seta on apical third; basal half with row of 4-5 stout posteroventral setae; apex with 1 anterior and 1 posterior preapical seta. Mid tibia with width reduced on ventral apical third, with row of 8 short spine-like setae; apex with short spur-like ventral seta; 1 anterodorsal and 1 posterodorsal seta near mid-length; 1 basal posterodorsal seta; apex with 1 dorsal and 1 posterior seta. Mid tarsomere 1 with 1 long anteroventral basal seta. Hind femur inflated, slightly broader than fore femur, without erect dorsal setae; with anteroventral row of stout setae along entire length; apical fourth with 2 anterodorsal, 1 anterior and 1 posterior seta. Hind trochanter without spine-like anteroventral setae. Hind tibia with 2 anterodorsal and $4-5$ posterodorsal setae; 1 preapical anterodorsal and 1 apical anteroventral seta; apical fourth with dense posterior setae. Hind tarsomere 1 without erect setae. All tarsomeres longer than tibia; ventral apical margin of tarsomere 4 of fore and midlegs somewhat pale, flattened and expanded; tarsomere 4 of hindleg not laterally compressed ventrally; tarsomere 5 of each leg lacking dorsoapical extension.

Wing. Infuscate with 1 long basal costal seta, longer than sctl; all veins lacking setulae; $\mathrm{R}_{4}$ and $\mathrm{R}_{5}$ distinctly divergent apically; bm-m complete, but weakened proximally; cell $\mathrm{dm}$ truncate, subequal in length to cell $\mathrm{bm} ; \mathrm{CuA}+\mathrm{CuP}$ reduced to streak. Halter brown.

Abdomen. Tergites and sternites clothed in setae; setae of posterior margin overlapping more than half length of following tergite. $\mathrm{T} 8 \mathrm{broad}$, one-third length of $\mathrm{T} 7$; posterior marginal setae slender, less than twice length of tergite.

Terminalia (Fig. 23). Cercus elongate and lying along dorsal edge of epandrium, deeply forked, U-shaped; apex of upper branch rounded, arched medially; lower branch longer than length of upper. Epandrium narrow, tapered apically. Surstylus weakly differentiated, apex rounded, not prolonged; ventral margin with row of stout setae. Hypandrium keellike, not greatly prolonged; apical margin truncate without medial notch; gonocoxal apodeme short, rounded; postgonite digitiform, divergent with arched, rounded apex. Phallus broad, apically flattened and spoon-shaped; ejaculatory apodeme L-shaped, longer than gonocoxal apodeme.

Female. Similar to male except as follows: scutellum with 1-2 pairs of discal setae; mid femur lacking row of stout posteroventral basal setae; mid tibia not narrowed apically, lacking row of spine-like setae; hind femur not strongly inflated, lacking anteroventral row of stout setae. Terminalia (not dissected): cercus slightly longer than epiproct, broad with rounded apex.

Distribution. This species is recorded from northern Queensland sites at $200 \mathrm{~m}$ and above $800 \mathrm{~m}$ (Fig. 19).

Etymology. The specific name is from the Latin divaricatus (spread apart, separate, fork), in reference to U-shaped male cercus.

Remarks. A single female specimen was collected at Cape Tribulation (Little Cooper Ck, $75 \mathrm{~m}, 16^{\circ} 10^{\prime} \mathrm{S} 145^{\circ} 27^{\prime} \mathrm{E}$ ), but a male from this locality is required to confirm its identity. 


\section{Hydropeza intricata sp. nov.}

\section{Figs 4, 20, 24}

Type material. Holotype $\widehat{\delta}$, labelled: “AUST: N.QLD:/ $14.7 \mathrm{~km} / \mathrm{up}$ Mt. Lewis Rd., $860 \mathrm{~m} / 22$. iv.1994, cascading/ creek, B. J. Sinclair/ 16³0'S 14517'E"; "HOLOTYPE/ Hydropeza/ intricata/ Sinclair [red label]" (AMS). Paratypes: Queensland: $2 \hat{\jmath} \hat{\sigma}, 4$ 우우 , same data as holotype (AMS); $3 \hat{\jmath}{ }^{\lambda}, 1$,, $31.6 \mathrm{~km}$ up Mt. Lewis Rd., $1000 \mathrm{~m}, 21$.iv.1994, cascading ck, $16^{\circ} 30^{\prime} \mathrm{S} 145^{\circ} 17^{\prime} \mathrm{E}$, B. J. Sinclair (CNC).

Diagnosis. This species is distinguished from other Queensland species by acrostichal setae extending to between first and second dorsocentral setae; male scutellum with 1 pair of elongate discal setae; male mid femur with row of short basal posteroventral setae and mid tibia with short row of spine-like setae on apical third; male hind trochanter with 2 spine-like anteroventral setae; and male cercus unmodified and apex of the phallus is inflated and highly complex. Females are distinguished from all other species by 1 pair of discal setae on the scutellum and segment 8 broad and inflated, not flattened.

Description. Head and abdomen dark brown, thorax brown with paler patches; coxae brownish yellow, legs progressively darker towards tips. Wing length $3-3.3 \mathrm{~mm}$.

Male. Head. Ocellar setae very long, erect, divergent, inserted posterior to anterior ocellus; ocellar tubercle with some long setulae; postocellar seta stout and dark; upper postocular setae stout and dark, lower setae fine and slender; postgenal setae similar to lower postoculars. Face without setulae. Scape and pedicel slightly paler than postpedicel; scape short and slender, slightly longer than length of globular pedicel; postpedicel not greatly prolonged, $3 \times$ longer than scape, basal portion elongate-oval, slightly longer than slender, straight apical portion; arista-like stylus distinctly longer than postpedicel, concolorous with postpedicel. Proboscis stout and robust, extended beyond mid-length of fore coxa, directed posteriorly; palpus half-length of proboscis, clothed in long pale and dark setae; apex of palpus rounded; apical third of palpus somewhat flattened with dense pubescence.

Thorax. Clothed in fine pruinescence; mesonotum brown, with postpronotal lobe, lateral margin and postalar ridge pale brown; pleura paler than notum, pale along sutures. Setae generally long and stout; $2-3$ acrostichal setulae extending to between 1 st and 2 nd dorsocentral setae, less than $0.5 \times$ length of dc; pprn with 1 seta and several short setulae; 1 long presut spal; 5 uniserial dc, about subequal in length with several setae interspersed; $3 \mathrm{npl} ; 1$ long psut spal and 1-2 finer setae; 1 pal seta; 1 pair of sctl, with 1 pair of finer outer marginal setae; disc of scutellum with 1 pair of long setae. Antepronotum with pair of pale setulae.

Legs. Coxae and femora ventrally yellowish-brown; remaining segments increasingly darker apically. Inner anterior margin of fore coxa with some 15-20 dark, variously lengthened and thickened spine-like setae, mostly concentrated apically; basal most seta longer than width of coxa. Anterior surface of mid and hind coxae with long brown setae. Legs clothed in very long setae as typical for genus, especially ventral faces. Fore femur straight, inflated (subequal in thickness to mid femur), with row of 2 stout anterior setae at apical fifth; 5-7 posterodorsal setae, apical 2 setae distinctly stouter. Fore tibia with 3 anteroventral setae on apical third; 2 anterodorsal and 2 posterodorsal setae; 1 anterodorsal preapical seta. Fore tarsomere 1 with 1 basal anteroventral and 1 preapical anterovental seta, more than $2 \times$ width of segment; 1 long basal ventral, 2 shorter ventral setae at middle and apex. Mid femur with row of 3-4 anterodorsal setae stouter towards apex; 1 anterior and 1 posterior seta on apical third; basal half with row of 4-5 short, stout posteroventral setae, less than width of femur; apex with 1 anterior, 1 dorsal and 1 posterior preapical seta. Mid tibia with width reduced on ventral apical third, with row of 5-8 short spine-like setae; apex with short spur-like ventral seta; 2 posterodorsal setae; apex with 1 dorsal seta. Mid tarsomere 1 with 1 long anteroventral basal seta. Hind femur inflated, nearly $1.5 \times$ broader than fore or mid femora, without erect dorsal setae; with anteroventral row of stout setae along entire length; apical fourth with 2 anterodorsal, 1 posterodorsal, 1 anterior and 1 posterior seta. Hind trochanter with 2 spine-like anteroventral setae. Hind tibia with 2 anterodorsal, 1 anteroventral and 4-5 posterodorsal setae; 1 preapical anterodorsal and 1 apical anteroventral seta; apical fourth with dense posterior setae. Hind tarsomere 1 without erect setae. Fore and mid tarsomeres slightly longer than tibia; ventral apical margin of tarsomere 4 of fore and midlegs somewhat pale, flattened and expanded; tarsomere 4 of hindleg not laterally compressed ventrally; tarsomere 5 of each leg lacking dorsoapical extension.

Wing. Infuscate with 1 long basal costal seta, longer than sctl; all veins lacking setulae; $\mathrm{R}_{4}$ and $\mathrm{R}_{5}$ distinctly divergent apically; bm-m complete; cell dm slightly produced, longer than cell bm; $\mathrm{CuA}+\mathrm{CuP}$ reduced to streak. Halter brown.

Abdomen. Tergites and sternites clothed in setae; setae of posterior margin overlapping more than half length of following tergite. T8 broad, nearly one-half length of T7; posterior marginal setae slender, some twice length of tergite.

Terminalia (Fig. 24). Cercus projected horizontally, shorter than epandrium, not forked or subdivided; apex sharply pointed ventrally. Epandrium broad with scattered setae. Surstylus slightly tapered, apex broadly rounded, not arched medially. Hypandrium subrectangular broad; apical margin shallowly notched; gonocoxal apodeme broad, rounded; postgonite absent. Phallus broad with complex apical half, inflated with 2 pairs of elongate, anteriorly projecting processes; apex of phallus arrowhead-shaped, projecting posteriorly; ejaculatory apodeme L-shaped, longer than gonocoxal apodeme.

Female. Similar to male except as follows: scutellum with 1 pair of discal setae; mid femur lacking row of stout posteroventral basal setae; mid tibia not narrowed apically, lacking row of spine-like setae; hind femur not strongly inflated, lacking anteroventral row of stout setae. Terminalia (not dissected): segment 8 inflated, broad; cercus slightly longer than epiproct, nearly $2 \times$ longer than wide; broad with rounded apex.

Distribution. This species is recorded from above $800 \mathrm{~m}$ on Mt. Lewis, Queensland (Fig. 20).

Etymology. The specific name is from the Latin intricatus (entangled, complicated), in reference to highly complex and unusual apex of the phallus.

Remarks. Female segment 8 is apparently inflated and not flattened as in related species. It is uncertain whether this is an artefact of drying, but other distinguishing features (e.g., acrostichals and scutellar setae) are consistent among specimens. 


\section{Hydropeza queenlandensis sp. nov.}

\section{Figs 7, 25}

Type material. Holotype $\widehat{\text { O }}$, labelled: “AUST: N.QLD: 4km/ up Mt. Edith Rd, $800 \mathrm{~m} /$ Danbulla S.F., malaise/ tp.across ck. 22-27.iv./ 1994, B. J. Sinclair/ $17^{\circ} 05^{\prime}$ S $145^{\circ} 38^{\prime}$ E”; "HOLOTYPE/ Hydropeza/ queenslandensis/ Sinclair [red

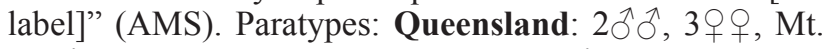
Hypipamee NP, 960 m, Barron R., 27.iv.1994, 17²6'S $145^{\circ} 29^{\prime}$ E, B. J. Sinclair (CNC); $3 \partial^{\lambda}, 11$, as holotype (AMS); 2 우, $14.7 \mathrm{~km}$ up Mt. Lewis Rd., $860 \mathrm{~m}, 22 . i v .1994$, cascading ck, $16^{\circ} 30^{\prime} \mathrm{S} 145^{\circ} 17^{\prime} \mathrm{E}, \mathrm{B}$. J. Sinclair (CNC); 11 우 , $31.6 \mathrm{~km}$ up Mt. Lewis Rd., $1000 \mathrm{~m}$, 21.iv.1994, cascading ck, $16^{\circ} 30^{\prime}$ S $145^{\circ} 17^{\prime} \mathrm{E}$, B. J. Sinclair (AMS, CNC); $5 \hat{\jmath}$, 4 , 0 우 , Paluma, Mt. Spec St. For., $3.6 \mathrm{~km}$ S Paluma Dam, ck, 29.iv.1994, 800 m, B. J. Sinclair (CNC).

Additional material. Queensland: $2 \circ \circ$, Mt. Finnigan, 14.v.1981, MT, D.H. Colless (ANIC).

Diagnosis. This species is distinguished from other Queensland species by restriction of the acrostichal setae anteriad to an imaginary line connecting the first (anteriormost) dorsocentral setae; male scutellum with several elongate discal setae; male mid femur with short row of basal posteroventral setae and mid tibia with short row of spine-like setae on apical third; male hind trochanter with single spine-like anteroventral seta; and male cercus deeply forked, Y-shaped. Females are distinguished from all other species by the highly setose scutellum.

Description. Head and abdomen dark brown, thorax brown with paler patches; coxae brownish yellow, legs progressively darker towards tips. Wing length $3.5-4 \mathrm{~mm}$.

Male. Head. Ocellar setae very long, erect, divergent, inserted posterior to anterior ocellus; ocellar tubercle with some long setulae; postocellar seta stout and dark; upper postocular setae stout and dark, lower setae fine and slender; postgenal setae similar to lower postoculars. Face without setulae. Scape and pedicel paler than postpedicel; scape short and slender, slightly longer than length of globular pedicel; postpedicel not greatly prolonged, $3 \times$ longer than scape, basal portion elongate-oval, longer than slender, straight apical portion; arista-like stylus slightly longer than postpedicel, concolorous with postpedicel. Proboscis stout and robust, extended slightly beyond mid-length of fore coxa, directed posteriorly; palpus less than half length of proboscis, clothed in long pale setae; apex of palpus rounded; apical third of palpus somewhat flattened with dense pubescence.

Thorax. Clothed in fine pruinescence; mesonotum brown, with postpronotal lobe, lateral margin and postalar ridge pale brown; pleura paler than notum, pale along sutures. Setae generally long and stout; 3-4 acrostichal setulae anterior to 1 st dorsocentral seta, less than $0.33 \times$ length of dc; pprn with 1 seta and several short setulae; 1 long presut spal; 5 uniserial $\mathrm{dc}$, about subequal in length, without intermixed finer setae; 3 npl; 1 long psut spal and 1-2 finer setae; 1 pal seta; 1 pair of sctl, with 1-2 pairs of finer outer marginal setae; disc of scutellum with several long setae. Antepronotum without pair of setae.

Legs. Coxae and femora ventrally yellowish-brown; remaining segments increasingly darker apically. Inner anterior margin of fore coxa with some 15 dark, variously lengthened and thickened spine-like setae, mostly concentrated apically; basal most seta longer than width of coxa. Anterior surface of mid and hind coxae with long brown setae. Legs clothed in very long setae as typical for genus, especially ventral faces. Fore femur straight, slightly inflated, with row of 2 stout anterior setae at apical fifth; 6-8 posterodorsal setae, stouter towards apex. Fore tibia with 2 anteroventral setae on apical third; 2 anterodorsal setae; 1 anterodorsal and 1 ventral preapical seta. Fore tarsomere 1 with 1 basal anteroventral and 1 preapical anterovental seta, more than $2 \times$ width of segment; 1 long basal ventral and 1 shorter ventral seta on basal third. Mid femur with 2-3 anterodorsal setae, 1 anterior seta and 1 posterodorsal seta on apical third; basal half with row of 3-4 stout posteroventral setae; apex with 1 anterior and 1 posterior preapical seta. Mid tibia with width reduced on ventral apical third, with row of 5 short spine-like setae; apex with short spur-like ventral seta; 1 anterior seta at mid-length; apex with 1 anterodorsal and 1 posterodorsal seta. Mid tarsomere 1 with 1 long anteroventral basal seta. Hind femur slightly broader than mid femur, without erect dorsal setae; with anteroventral row of stout setae along entire length; apical fourth with 2 anterodorsal, 1 anterior and 1 posterior seta. Hind trochanter with single spine-like anteroventral seta. Hind tibia with 2 anterodorsal and 4 posterodorsal setae; 1 apical anteroventral seta; apical third with dense posterior setae. Hind tarsomere 1 without erect setae. Tarsomeres of fore and midlegs longer than tibia; ventral apical margin of tarsomere 4 of fore and midlegs somewhat pale, flattened and expanded; tarsomere 4 of hindleg not laterally compressed ventrally; tarsomere 5 of each leg lacking dorsoapical extension.

Wing. Infuscate with 1 long basal costal seta, longer than sctl; all veins lacking setulae; $\mathrm{R}_{4}$ and $\mathrm{R}_{5}$ distinctly divergent apically; bm-m complete; cell $\mathrm{dm}$ truncate to slightly produced, longer than length of cell $\mathrm{bm} ; \mathrm{CuA}+\mathrm{CuP}$ reduced to streak. Halter brown.

Abdomen. Tergites and sternites clothed in setae; setae of posterior margin overlapping more than half length of following tergite. $\mathrm{T} 8$ broad, more than half length of T7; posterior marginal setae slightly shorter than preceding tergites.

Terminalia (Fig. 25). Cercus elongate and projected, deeply forked, Y-shaped; apex of upper branch flattened, with short, sharp projection medially; lower branch subequal in length to upper. Epandrium narrow, tapered apically. Surstylus weakly differentiated, apex prolonged as stout, sharp thorn-like projection. Hypandrium keel-like, not greatly prolonged; apical margin with deep medial notch; gonocoxal apodeme short, rounded; postgonite digitiform, divergent, with hooked apex. Phallus broad, apically flattened and spoon-shaped; ejaculatory apodeme longer than gonocoxal apodeme.

Female. Similar to male except as follows: scutellum highly setose; mid femur lacking row of stout posteroventral basal setae; mid tibia not narrowed apically, lacking row of spinelike setae; hind femur lacking anteroventral row of stout setae. Terminalia (not dissected): cercus slightly longer than epiproct, slender with rounded apex.

Distribution. This species is widespread in the high tablelands in the wet tropics region of northern Queensland (Fig. 7).

Etymology. The specific name refers to the distribution of this species. 


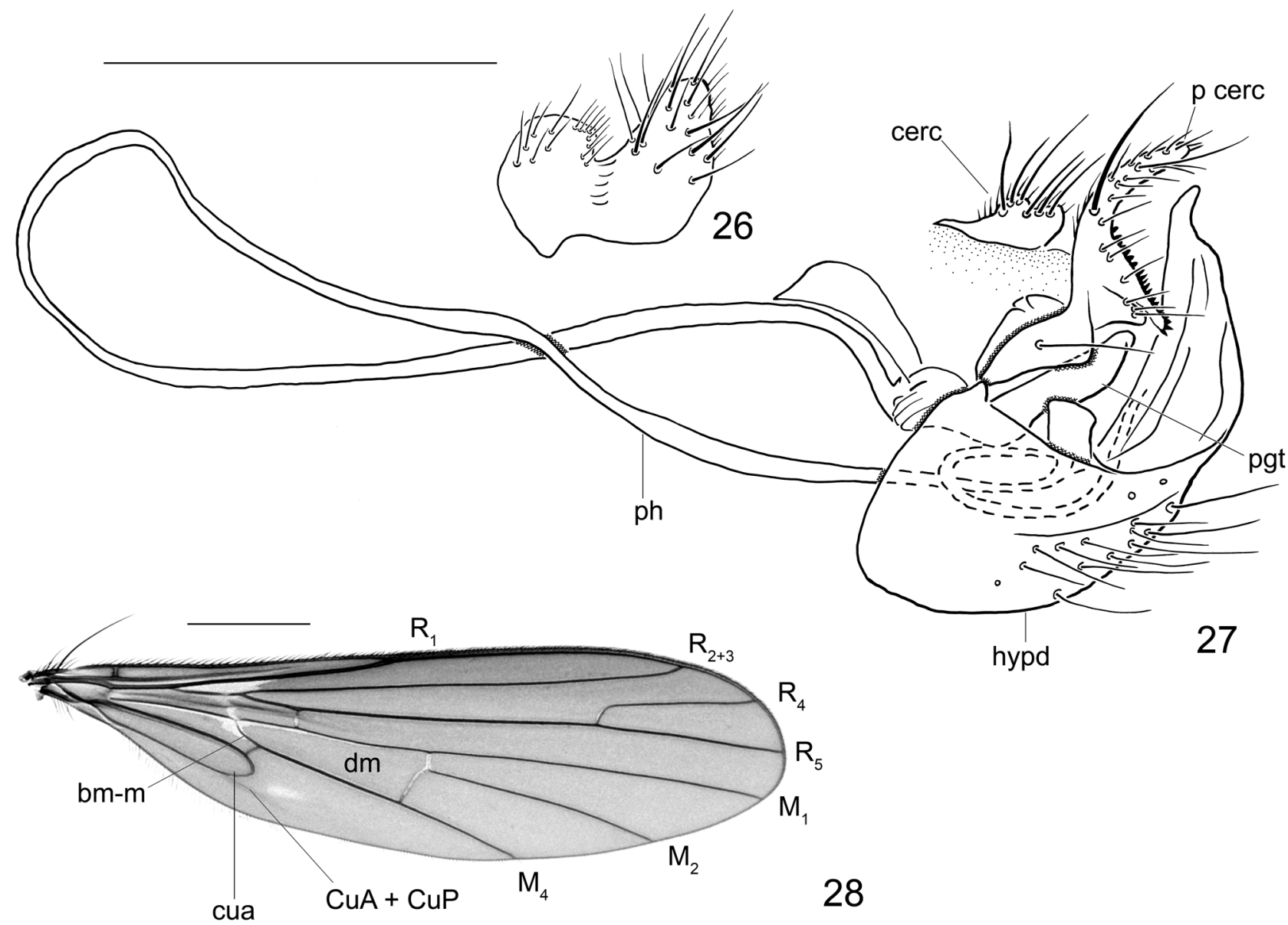

Figures 26-28. Hydropeza tasmanica. (26) Male epandrium, lateral view. (27) Male terminalia with epandrium removed, lateral view. (28) Wing. Abbreviations: $b m-m$, basal medial crossvein; cerc, cercus; cua, anterior cubital cell; $C u A+C u P$, anterior branch of cubital vein plus posterior branch of cubital vein; $d m$, discal medial cell; hypd, hypandrium; $M$, medial vein; $p$ cerc, posterior cercus; pgt, postgonite; $p h$, phallus; $R$, radial vein. Scale bars $=0.4 \mathrm{~mm}$, except Fig. 28 where scale bar $=0.1 \mathrm{~mm}$.

Remarks. The two females from Mt. Finnigan were excluded from the type series because the acrostichal setae extend beyond the first dorsocentrals. Collection of male specimens from this locality is required to confirm species identity.

\section{Hydropeza tasmanica sp nov.}

Figs 5, 13-17, 22, 26-28

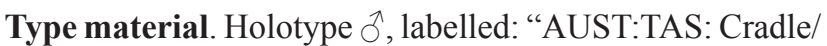
Mtn N.P., Pencil Pine/Tr., 20.ii.1994/ Pencil Pine Ck., 800m/B. J. Sinclair"; "HOLOTYPE/ Hydropeza/ tasmanica/ Sinclair [red label]" (AMS). Paratypes: Tasmania: 1ㅇ, nr. Collingwood Ck on Lyell Hwy, 27.i.1989, buttongrass/ heath, ypans, D. Bickel (AMS); $3 \hat{\gamma}$, 5 우, Collins Cap, W Mt.

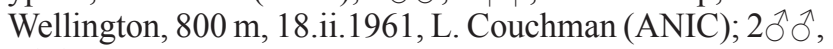
2우, Cradle Mtn NP, Pencil Pine Tr., 20.ii.1994, Pencil Pine Ck, 800 m, B. J. Sinclair (CNC); 10̂, Cradle Mtn NP, Overland/ Dove Lake Tr., 21.ii.1994, 800-1000 m, B. J. Sinclair (CNC); 1ठ, 3 우, Ferntree Gully, ii.1928, I. Smith (ANIC); 10̂, 2q9, 8 mi E Gormanston, 28.i.1948, Key, Carne \& Kerr (ANIC); 1ิึ, 19, Hartz Mont., 10.xii.1922, A. Tonnior (ANIC); 19, Huon-Picton River junction, 18.ii.1967, A. Neboiss (NMV); 1 ${ }^{\lambda}$, King River, 4.ii.1923, A. Tonnoir (ANIC); 1ㅇ, 5 mi. W King William Saddle, 4.xi.1961, N. Dobrotworsky (AMS); 7ðึㅅ, 7우우, Lyell
Hwy Franklin/Gordon Wild Rivers NP, 19.ii.1994, Franklin R., B. J. Sinclair (CNC); $3 \hat{\jmath} \jmath^{\lambda}, 2$ 우, Mt. Barrow St. Res.,

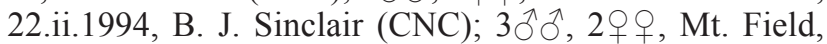
19.xii.1922, A. Tonnoir (ANIC); 10 , Mt. Field, 11.xi.1953, S. Butler (NMV); $5 \hat{\jmath} \widehat{\jmath}, 3 ㅇ+$, Mt. Field NP, Lake Dobson, small stream inflow, 18.ii.1994, 1020 m, B. J. Sinclair (CNC); 1今, 1오. Mt. Field NP, Mawson Plateau, $1200 \mathrm{~m}$, alpine sweeping, 25.i.1989, D. Bickel (AMS); 2오, Mt. Rufus, 27.i.1948, Key, Carne \& Kerr (ANIC); $2{ }^{\lambda}{ }^{\lambda}, 1$, 9 , Myrtle Forest, 29.i.1937, G.\&C. Davis (ANIC); $2 \delta^{\lambda}, 19$ 우우, Pelion Hut, $3 \mathrm{kmS}$ Mt. Oakleigh, $41^{\circ} 50^{\prime} \mathrm{S} 146^{\circ} 03^{\prime} \mathrm{E}, 860 \mathrm{~m}$, vi,x.1990, 8.i.-12.ii., 9.iv.-6.vi.1991, D. Naumann (AMS, ANIC); 1 0,6 우우, Pelion Hut, 8.i.1991, Nielsen, Edwards (AMS); 1 9 , Pelion Plain 1 kmS, 7.vi.1990 (AMS); 10, 4오오, Scott Peak, Dam Rd. \& Clear Ck, 4-5.ii.1989, wet scler; MT, D. Bickel (AMS).

Diagnosis. This is the largest Australian species of Hydropeza, distinguished by its dark brown coloration, knob-like ventral process on the male mid femur and slender hind femur.

Description. Head and abdomen dark brown, thorax brown with paler patches; coxae often pale brown, legs progressively darker towards tips. Wing length $6-7.2 \mathrm{~mm}$.

Male. Head (Fig. 13). Ocellar setae very long, erect, divergent, inserted posterior to anterior ocellus; ocellar 
tubercle with some long setulae; postocellar and postocular setae stout and dark; postgenal setae similar to postoculars. Lower half of face with row of long setulae on inner margin of eye. Scape long and slender, about $2 \times$ length of globular pedicel; postpedicel elongate, basal portion onion-shaped, shorter than slender, straight apical portion; arista-like stylus slightly longer than apical portion of postpedicel, concolorous with postpedicel. Proboscis stout and robust, long, extended well beyond mid-length of fore coxa, directed posteriorly; palpus about $0.75 \times$ length of proboscis, clothed in long dark setae, some dorsolateral setae stout; apex of palpus pointed; apical third of palpus flattened with dense pubescence.

Thorax. Clothed in fine pruinescence; mesonotum brown, with postpronotal lobe and base of transverse suture pale brown; pleura paler than notum, with dark patches; pale along sutures. Setae generally long and stout; 3-4 acrostichal setulae anterior to 1 st dorsocentral seta, about $0.33 \times$ length of dc; pprn with 1 seta and several dark, short setulae; 1 long presut spal and 1-2 finer short setae; 5 uniserial dc, about subequal in length, with intermixed finer setae; $3 \mathrm{npl}$; 1 long psut spal and 1-2 finer setae; 1 pal seta; 1 pair of sctl, with 1-2 pairs of finer outer marginal setae. Antepronotum with pair of long stout setae.

Legs. Brown, increasingly darker apically. Inner anterior margin of fore coxa with more than 20 dark variously lengthened and thickened spine-like setae, mostly concentrated apically and mid-basally; basal most seta longer than width of coxa (Fig. 14). Anterior surface of mid and hind coxae with long brown setae. Legs clothed in very long setae as typical for genus, especially ventral faces. Fore femur slightly arched, with row of 6 anterior setae, apical fifth with 2 longer and stouter anterior setae, longer than width of femur; 4-5 posterodorsal setae and 1 posterior seta at basal third; 1 long preapical posterior seta. Fore tibia with 4 anteroventral, 4 anterodorsal, 4 posteroventral and 4 posterior setae; apical fifth with 1 dorsal and 2 posterodorsal setae; 1 anteroventral and 1 anterodorsal preapical seta. Fore tarsomere 1 with 1 dorsal and 1 anterodorsal near mid-length; 1 ventral seta on basal fourth; apex with 1 anterodorsal and 1 posterodorsal seta. Mid femur with knob-like process at basal third, bearing several short spine-like setae (Fig. 15); 2 long stout setae proximal to process, longer than width of femur (Fig. 16); 3 anterodorsal and 3 posterodorsal setae on distal half; apex with 1 anterodorsal and 1 posterodorsal preapical seta. Mid tibia with anteroventral notch on apical sixth, with distal row of short spine-like setae terminating in pair of claw-like apical setae (Fig. 16); opposite notch with sinuous spur-like anterodorsal seta; 2 anterodorsal setae, 4 posterodorsal setae and 2 anterior setae. Mid tarsomere 1 with ventral curve at base, with long anterior seta; 1 anterodorsal, 1 posterodorsal seta; apex with several preapical stout setae. Hind femur with erect dorsal setae; 1 preapical anterior, 2 preapical anterodorsal and 1 preapical posterodorsal setae on apical fourth, longer than width of femur. Hind tibia with 4-5 anterodorsal and posterodorsal setae; 2 preapical anterior setae; 1 anteroventral seta on apical third. Hind tarsomere 1 with several dorsal and preapical setae. Tarsomeres of fore and midlegs much longer than tibia; ventral apical margin of tarsomere 4 of fore and midlegs somewhat pale, flattened and expanded; tarsomere 4 of hindleg laterally compressed ventrally, keel-like, extending beyond apex; tarsomere 5 of each leg lacking dorsoapical extension (Fig. 17).
Wing (Fig. 28). Infuscate with 1 long basal costal seta, longer than sctl; all veins lacking setulae; $\mathrm{R}_{4}$ and $\mathrm{R}_{5}$ distinctly divergent apically, base of $\mathrm{R}_{4}$ often weakened; bm-m complete; cell $\mathrm{dm}$ truncate to slightly produced, longer than length of cell bm; $\mathrm{CuA}+\mathrm{CuP}$ present only as short streak. Halter brown.

Abdomen. Tergites and sternites clothed in setae; setae of posterior margin overlapping more than half length of following tergite. T8 broad, more than half length of T7; posterior marginal setae greatly reduced in length compared to preceding tergites.

Terminalia (Figs 26, 27). Cercus divided into two components: anterior cercus small, thinly sclerotized sclerite surrounding anus, bearing long setae; posterior cercus sickle-shaped, heavily sclerotized with peg-like setae along posteromedial margin; apex of posterior cercus tapered, bearing stout terminal seta. Epandrium small, bilobed with longer setae of posterior lobe; lamellae separated dorsally beneath cercus by wide membranous gap; epandrium not prolonged posteriorly. Surstylus not differentiated. Hypandrium keel-like, prolonged dorsally into phallic guide; gonocoxal apodeme inconspicuous; long setae on posterior half extending to base of dorsal extension; postgonite finger-like, slightly curved. Phallus long and filamentous, extending anteriorly into abdomen for 2-3 segments, twisted into figure-8, emerging from phallic guide of hypandrium; ejaculatory apodeme reduced not plate-like.

Female. Similar to male except as follows: mid femur and tibia lacking modified setae and processes. Terminalia (not dissected): cercus long and slender with rounded apex.

Distribution. This species is restricted to Tasmania (Fig. 22), occurring in upland streams and rivers from western, northeastern and southern Tasmania.

Etymology. The specific name refers to the distribution of this species, which is widespread in Tasmania.

Remarks. The shape of the hypandrium and epandrium is very similar to $H$. wardi Sinclair \& McLellan from New Zealand.

\section{Hydropeza unguicula sp. nov.}

$$
\text { Figs 6, 18, } 21
$$

Type material. Holotype $\hat{\jmath}$, Tasmania: "Pelion Tas/ June 1990/ INaumann"; "HOLOTYPE/ Hydropeza/ unguicula/ Sinclair [red label]" (ANIC).

Diagnosis. This Tasmanian species is recognized by the modified male forelegs, especially the claw-like process of tarsomere 1 and pointed spatulate process of tarsomere 4 of the male midleg.

Description. Head, thorax and legs dark brown, abdomen slightly paler. Wing length $3.8 \mathrm{~mm}$.

Male. Head. Ocellar setae long, erect, divergent, inserted between anterior and posterior ocelli; ocellar tubercle with several short setulae; postocellar and postocular setae dark, stout to slender; postgenal setae similar to postoculars. Lower half of face lacking setulae. Scape long and slender, about $2 \times$ length of globular pedicel; postpedicel elongate, basal portion not broader than pedicel, shorter than slender, tapered apical portion; stylus slightly longer than apical portion of 
postpedicel, concolorous with postpedicel. Proboscis stout and robust, long, extended well beyond mid-length of fore coxa, directed posteriorly; palpus about $0.75 \times$ length of proboscis, clothed in long setae, apex of palpus rounded (view of apex obscured by wing).

Thorax. Clothed in fine pruinescence; mesonotum brown; pleura paler along sutures. Setae not distinctly long or stout; 6 acrostichal setulae anterior to 1 st dorsocentral seta, about $0.25 \times$ length of dc; pprn with 1 seta and one dark setula; 1 long presut spal and several finer short setulae; 5 uniserial dc, with intermixed finer setae; $3 \mathrm{npl}$; 1 long psut spal and 1-2 finer setulae; 1 pal seta; 1 pair of sctl, with 1 pair of finer outer marginal setae. Antepronotum with pair of slender setae.

Legs. Brown, increasingly darker apically. Inner anterior margin of fore coxa with more than 20 dark, short and thickened spine-like setae, mostly concentrated apically and mid-basally; apical setae longer than basal setae of coxa. Anterior surface of mid and hind coxae with long brown setae. Legs not clothed in very long setae as typical for genus. Fore femur slightly arched with long, silky ventral setae; nearly subequal to width of femur; base with pair of long, slender setae, nearly twice width of femur; distal half with distinctly separated brush of long, dark posterodorsal setae. Fore tibia slightly arched medially; posterior face with long, scattered setae, similar to fore femur; apical half with numerous, scattered, spine-like anterodorsal setae; apical half with 2 widely spaced, posteroventral spine-like setae. Fore tarsomere 1 shorter than segment 2, with long claw-like apical process directed ventrally (Fig. 18); base with spinelike anteroventral seta, two-thirds length of tarsomere; apex with spine-like posteroventral, posterior and anteroventral preapical seta; claw-like process tapered and twisted to posterior face of tarsi, bearing 4 long divergent setae, longer than tarsomeres 1 and 2 combined and several stout subapical setae. Fore tarsomere 2 with 1 long radiating seta similar to long setae on claw-like process; with several stout preapical setae. Mid femur with posteroventral row of widely spaced setae, length nearly twice width of femur; basal half with 3 long ventral setae, twice width of femur; 1 anterodorsal on distal fifth; apex with 1 anterodorsal preapical seta. Mid tibia with 2 anterodorsal, 3 anteroventral and row of posteroventral setae; apex with several preapical setae. Mid tarsomere 1 lacking erect stout setae. Hind femur with 1 anterodorsal setae on apical fifth and 1 preapical anterodorsal seta. Hind tibia with 2 anterodorsal setae, 2 anteroventral setae and 1 dorsal seta on apical fourth; 1 anterodorsal and 1 anteroventral preapical seta. Hind tarsomere lacking erect stout setae. Tarsomeres of foreleg longer than tibia; ventral apical margin of tarsomere 4 of foreleg flattened and expanded; midleg tarsomere 4 expanded into pointed spatulate projection, longer than segment; tarsomere 4 of hindleg laterally compressed ventrally, keel-like, extending slightly beyond apex; tarsomere 5 of each leg lacking dorsoapical extension.

Wing. Infuscate with 1 long basal costal seta, slightly longer than sctl; all veins lacking setulae; $\mathrm{R}_{4}$ and $\mathrm{R}_{5}$ distinctly divergent apically; bm-m complete; cell dm slightly produced, shorter than length of cell bm; $\mathrm{CuA}+\mathrm{CuP}$ absent. Halter brown.

Abdomen. Tergites and sternites clothed in setae; setae of posterior margin overlapping more than half length of following tergite.

Terminalia (undissected). Cercus divided into small, flat, horizontal dorsal lamellae surrounding anus, and slender, parallel-sided, medially arched lateral lamellae. Epandrium similar in form to lateral cercal lamella, arched medially. Hypandrium cone-shaped; postgonite not observed. Paired spine-like lobes arching from near base of phallus; phallus long and filamentous, recurved above terminalia.

Female. Unknown.

Distribution. Only the male holotype of this species is known, collected during winter (June) from Cradle Mountain National Park, Tasmania (Fig. 21).

Etymology. The specific name is from the Latin unguiculus (claw, talon), in reference to the claw-like projection from tarsomere 1 of the male foreleg.

Remarks. The male terminalia was not dissected, because only a single specimen is known. However, the highly modified forelegs should facilitate species recognition.

\section{Discussion}

The cladistics analysis resulted in four equally parsimonious trees, with length $=40, \mathrm{CI}$ (consistency index) $=0.6$; CI excluding uninformative characters $=0.53$, RI (retention index $)=0.73$, and $\mathrm{RC}$ (rescaled consistency index $)=0.44$. The trees differed in the position of the Chilean species, $H$. curicoa Sinclair \& Plant, as sister group to the Queensland species or sister to $H$. tasmanica $+H$. wardi group and the arrangement of the species in the Queensland group. In the strict consensus tree, the $H$. curicoa branch is collapsed forming a trichotomy with the Queensland species group and the $H$. tasmanica $+H$. wardi group. One of the four trees was chosen as representative and used to trace the character distributions (Fig. 29).

In the present analysis the New Zealand species are no longer grouped into two clades as reported by Sinclair \& McLellan (2004). Hydropeza aptera and H. unguicula are sisters to the remaining species, but this could be an artefact due to the effects of wing loss in the former and the unknown details of the male terminalia in the latter. In contrast, the $H$. longipennae group (which includes $H$. milleri) was sister to the remaining species of Hydropeza in the earlier analysis (Sinclair \& McLellan, 2004). Hydropeza akatarawa is no longer assigned to the $H$. clarae group due to differences in leg chaetotaxy and complete bm-m crossvein. Three New Zealand species form a monophyletic group on the basis of an incomplete bm-m crossvein (character 9.1). Hydropeza tasmanica and $H$. wardi form a monophyletic group united on the basis of peg-like setae on the posterior cercus (character 19.1) and prolongation of the hypandrium (character 20.1). Hydropeza curicoa is sister to the Queensland species group ( $H$. divaricata, $H$. angulata, $H$. intricata, $H$. cornuta, $H$. queenslandensis) on the basis of the forked posterior cercus (character 21.1) and articulated postgonite (character 22.2). The monophyly of the clade comprising the six species from Queensland is supported by presence of an inflated hind femur (character 13.1).

Transantarctic relationships have been documented in several lineages of Empidoidea (Daugeron et al., 2009; Sinclair, 2010). Within Hydropeza, both New Zealand + Australia and Australia + southern South America faunal connections are illustrated. These phylogenetic patterns are consistent with the belief that Hydropeza was well distributed 


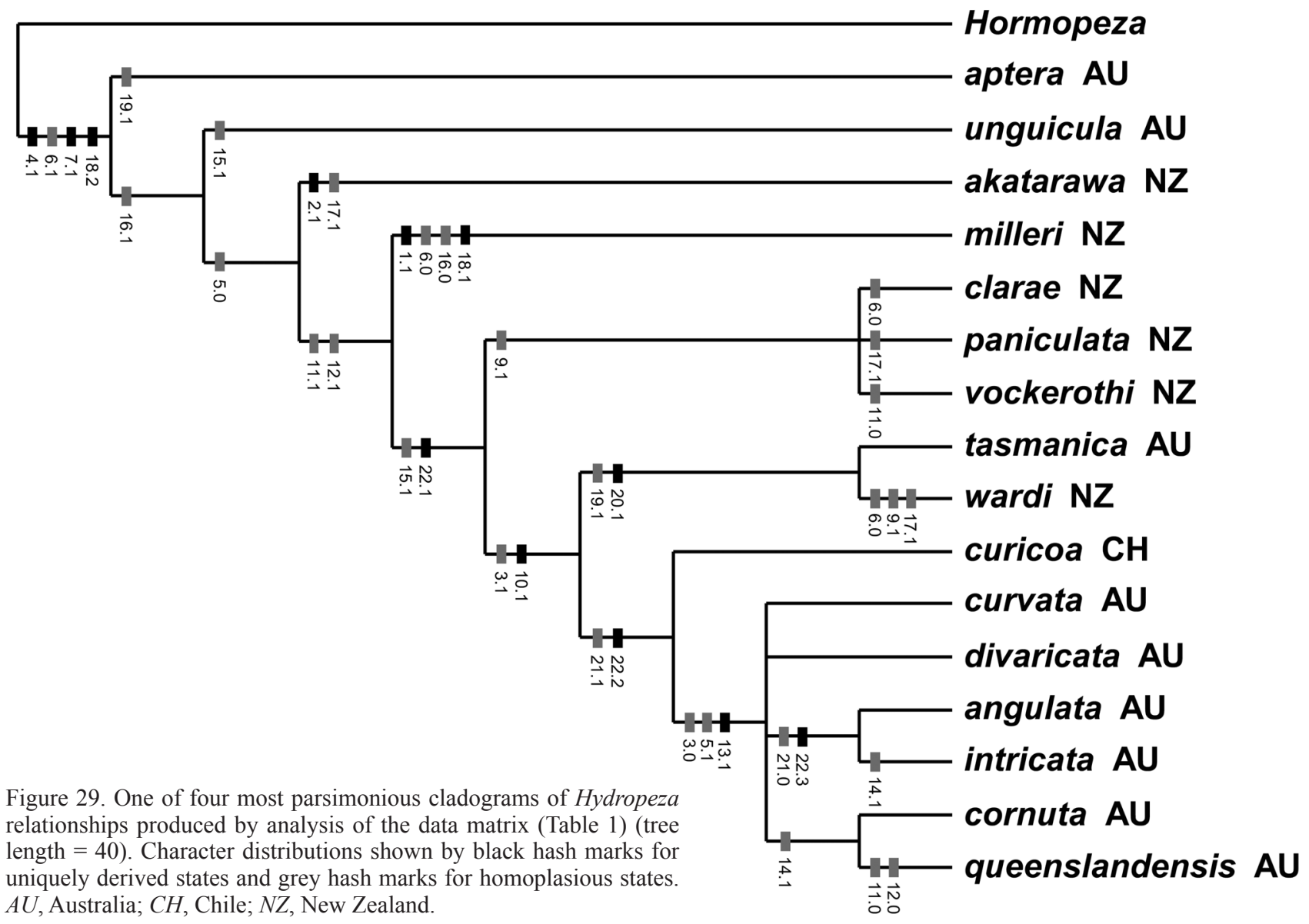

(Fig. 30) and diversified across former Gondwanan continents following the separation of southern South America from Africa in the Early Cretaceous. Therefore the origin of the genus is hypothesized to date from this period or earlier. The geographic patterns in Hydropeza are similarly as complex as among the Ceratomerinae (Sinclair, 2010), which also include species adapted to a winter flight period.

In Australia, Hydropeza is presently known only from Tasmania and northern Queensland (Wet Tropics) (Fig. 30). A similar widely disjunct distribution is also recorded for the genus Apterodromia Oldroyd (Hybotidae), although also recorded from Western Australia (Sinclair \& Cumming, 2000). The aquatic fly fauna of eastern Australia is generally well surveyed using a variety of trapping methods and the disjunct distribution of the genus is possibly not an artefact due to lack of collecting. The absence of the genus from Victoria, New South Wales and southeastern Queensland cannot be explained, especially since a wide range of habitats that are suitable to Hydropeza are present in this region. Sampling surface flies with dip nets may produce additional samples from these other regions.

It is rather remarkable that there are five variously sympatric species on Mt. Lewis above $700 \mathrm{~m}$, while only six species are known from the entire Wet Tropics. However, the specimens are all mostly from a single collecting trip, and concentrated efforts elsewhere in this region will likely expand species ranges. High endemism was also found among flightless insects in the Carbine Uplands, which includes Mt. Lewis (Yeates et al., 2002).
Table 1. Data matrix for Hydropeza, listing 17 terminal taxa and 22 characters used in the analysis. See Table 2 for character descriptions. Character states were scored 0-3, en-dash for inapplicable data and ? for unknown data.

\begin{tabular}{llll}
\hline & Characters \\
Taxa & 0000000001 & 1111111112 & 22 \\
& 1234567890 & 1234567890 & 12 \\
\hline Hydropeza akatarawa & 0101011100 & 0000011200 & 00 \\
H. angulata & 0001111101 & 1110110200 & 03 \\
H. aptera & $000111--0$ & 0000000210 & 00 \\
H. clarae & 0001001110 & 1100110200 & 01 \\
H. cornuta & 0001111101 & 1111110200 & 12 \\
H. curicoa & 0011011101 & 1100110200 & 12 \\
H. curvata & 0001111101 & 1110110200 & 12 \\
H. divaricata & 0001111101 & 1110110200 & 12 \\
H. intricata & 0001111101 & 1111110200 & 03 \\
H. milleri & 1001001100 & 1100000100 & 00 \\
H. paniculata & 0001011110 & 1100111200 & 01 \\
H. queenslandensis & 0001111101 & 0011110200 & 12 \\
H. tasmanica & 0011011101 & 1100110211 & 01 \\
H. unguicula & 0001111100 & 0000110200 & $0 ?$ \\
H. vockerothi & 0001011110 & 0100111200 & 01 \\
H. wardi & 0011001111 & 1100110211 & 01 \\
Hormopeza & 0000100000 & 0000000000 & 00 \\
\hline
\end{tabular}




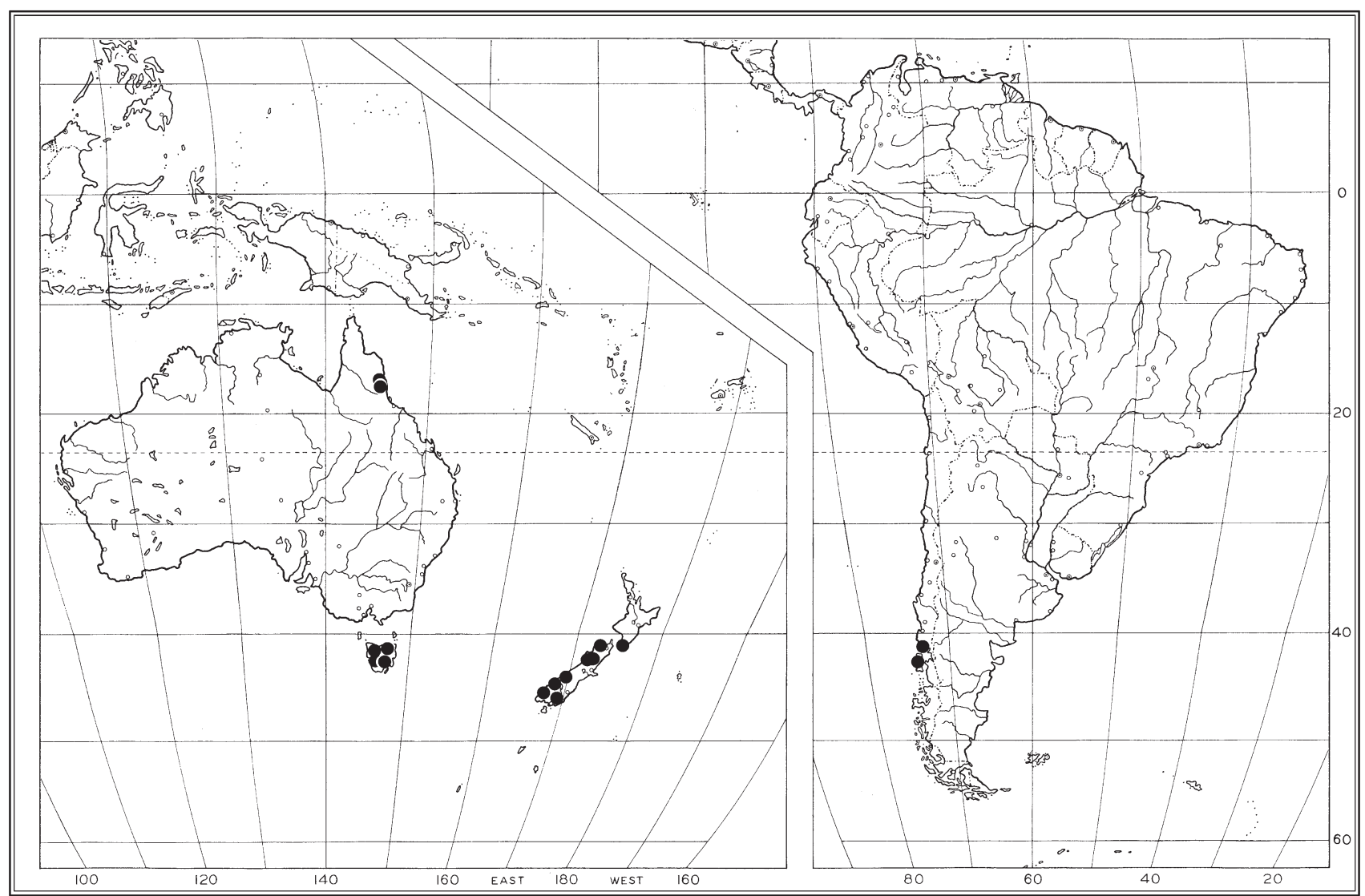

Figure 30. Known overall distribution of Hydropeza $(\bullet)$; large cities (o).

Table 2. Characters used in the analysis of Hydropeza.

1 Body colouration: brown to black (0); clothed in distinct blue pruinescence (1)

2 Postpedicel: with apical stylus (0); lacking apical stylus (1)

3 Face: bare (0); setose (1)

4 Prosternum: separate (0); fused to proepisternum (1)

5 Antepronotum: with pair of setae (0); setae greatly reduced, slender or absent (1)

6 Acrostichals: full length of scutum (0); absent or greatly reduced (1)

7 Stigma: present (0); absent (1)

8 Subcosta: complete (0); incomplete (1)

9 bm-m: complete (0); abruptly terminated, incomplete (1)

10 Male mid femur: posteroventral row of setae absent (0); posteroventral row of setae at base (1)

11 Male mid tibia: row of setae absent (0); row of spine-like ventral setae on apical third (1)

12 Male mid tibia: apical spur-like seta absent (0); apical spur-like seta present (1)

13 Male hind femur: slender (0); inflated, broader than fore and mid femora (1)

14 Male hind trochanter: lacking spines (0); 1-2 spine-like setae present (1)

15 Male tarsomere 4 of fore- and midlegs: unmodified (0); apex flattened and expanded (1)

16 Tarsomere 4 of hindleg: unmodified (0); keel-shaped (1)

17 Tarsomere 5 extension: absent (0); present (1)

18 Epandrial lamellae: not separated (0); narrowly and weakly connected (1); distinctly separated (2)

19 Posterior cercus: lacking brush of setae (0); brush of short, peg-like setae (1)

20 Hypandrium: without prolongation (0); prolonged into tapered phallic guide (1)

21 Cercus shape: unbranched (0); posterior section forked (1)

22 Postgonites: appressed or fused to phallus (0); short, finger-like (1); articulated (2); arched medially to opposite pgt and appressed or fused (3) 
ACKNOWLEDGMENTS. I am indebted to the following curators and their respective institutions for the loan of specimens: D. J. Bickel (AMS), P. S. Cranston (ANIC), K. Walker (NVM). The SEMs were taken by G. Avern (AMS). Hans Ulrich (Bonn, Germany) provided advice concerning Greek and Latin grammar as related to nomenclature. Michael Driessen (Department of Primary Industries, Parks, Water and Environment, Hobart, Australia) provided habitat details and digital image of the type locality of $H$. aptera. Dan Bickel kindly provided the habitus drawing of $H$. aptera by Hannah Finlay. Jeffrey Cumming (CNC) kindly commented on an earlier draft and the southern continents base map was provided by Scott Brooks (CNC). Dan Bickel and Adrian Plant (Cardiff, Wales) kindly reviewed an earlier version of the manuscript.

\section{References}

Bickel, D. 2006. Papallacta (Diptera: Dolichopodidae), a new stenopterous genus from the páramo of Ecuador. Tijdschrift voor Entomologie 149: 209-213. http://dx.doi.org/10.1163/22119434-900000201

Cumming, J. M., and D. M. Wood. 2009. Adult morphology and terminology. In Manual of Central American Diptera, vol. 1., ed. B.V. Brown, A. Borkent, J. M. Cumming, D. M. Wood and M. Zumbado, pp. 9-50. Ottawa: National Research Council Research Press.

Daugeron, C., C. A. D’Haese, and A. R. Plant. 2009. Phylogenetic systematics of the gondwanan Empis macrorrhyncha group (Diptera, Empididae, Empidinae). Systematic Entomology 34: 635-648. http://dx.doi.org/10.1111/j.1365-3113.2009.00490.x

Driessen, M. M., J. B. Kirkpartrick, and P. B. McQuillan. 2013. Shifts in composition of monthly invertebrate assemblages in moorland differed between lowland and montane locations but not fire-ages. Environmental Entomology 42(1): 58-73. http://dx.doi.org/10.1603/EN12322

Hackman, W. 1964. On reduction and loss of wings in Diptera. Notulae Entomologicae 44: 73-93.

Miller, D. 1923. Material for a Monograph of the Diptera fauna of New Zealand: Part III-Family Empididae. Transactions and Proceedings of the New Zealand Institute 54: 437-464.

Saigusa, T. 2006. Homology of wing venation of Diptera. Unpublished handout distributed at the 6th International Congress of Dipterology, Fukuoka, Japan, 26 pp.

Sinclair, B. J. 1995. New species of Hormopeza Zetterstedt from South Africa and Tasmania (Diptera: Empididae). Annals of the Natal Museum 36: 203-208.

Sinclair, B. J. 1999. Review of the genera Dipsomyia Bezzi, Zanclotus Wilder, and an allied new Gondwanan genus (Diptera: Empidoidea, Ragas-group). Entomological Science 2: 131-145.
Sinclair, B. J. 2010. Revision and phylogenetic systematics of the Neotropical Ceratomerinae (Diptera: Empidoidea: Brachystomatidae). Arthropod Systematics \& Phylogeny 68(2): 197-228.

Sinclair, B. J. 2011. Revision of the New Zealand genus Adipsomyia (Diptera: Empidoidea: Brachystomatidae: Trichopezinae), with key to local Empidoid family and selected genus groups. The New Zealand Entomologist 34: 30-36. http://dx.doi.org/10.1080/00779962.2011.9722205

Sinclair, B. J., and J. M. Cumming. 2000. Revision of the genus Apterodromia (Diptera: Empidoidea), with a redefinition of the tribe Ocydromiini. Records of the Australian Museum 52(2): 161-186. http://dx.doi.org/10.3853/j.0067-1975.52.2000.1313

Sinclair, B. J., and J. M. Cumming. 2006. The morphology, higherlevel phylogeny and classification of the Empidoidea (Diptera). Zootaxa 1180: 1-172.

Sinclair, B. J., and C. Hoffeins. 2013. New fossil species of Ragas Walker (Diptera: Empididae) in Baltic amber (Tertiary, Eocene). Bonn zoological Bulletin 62(1): 92-99.

Sinclair, B. J., and I. D. McLellan. 2004. Revision of the New Zealand species of Hydropeza Sinclair (Diptera: Empididae: Ragas-group). Invertebrate Systematics 18: 627-647. http://dx.doi.org/10.1071/IS04015

Sinclair, B. J., and A. R. Plant. 2008. A new species of Hydropeza Sinclair from Chile (Diptera: Empididae). Acta Entomológica Chilena 31(2) (2007): 7-10.

Stuckenberg, B. R. 1999. Antennal evolution in the Brachycera (Diptera), with a reassessment of terminology relating to the flagellum. Studia dipterologica 6: 33-48.

Swofford, D. L. 1998. PAUP*. Phylogenetic analysis using parsimony (*and other methods). Version 4. Sunderland, Massachusetts, USA: Sinauer Associates.

Ulrich, H. 2003. How recent are the Empidoidea of Baltic amber. Studia dipterologica 10(1): 321-327.

Walker, F. 1837. Notes on Diptera. Entomological Magazine 4(1836): 226-230.

Yeates, D. K., P. Bouchard, and G. B. Monteith. 2002. Patterns and levels of endemism in the Australian Wet Tropics rainforest: evidence from flightless insects. Invertebrate Systematics 16: 605-619.

http://dx.doi.org/10.1071//T01032

Manuscript submitted 3 February 2016, revised and accepted 6 April 2016. 